\title{
Origin and chemical evolution of formation waters from Silurian-Devonian strata in the Illinois basin, USA
}

\author{
ALAN M. STUEBER ${ }^{1}$ and LYNN M. WALTER ${ }^{2}$ \\ ${ }^{1}$ Department of Geography and Earth Science, Southern Illinois University, Edwardsville, IL 62026, USA \\ ${ }^{2}$ Department of Geological Sciences, University of Michigan, Ann Arbor, MI 48109, USA
}

(Received April 9, 1990; accepted in revised form October 15, 1990)

\begin{abstract}
A suite of formation-water samples from Silurian-Devonian reservoirs in the Illinois basin has been analyzed for major, minor, and trace element concentrations and for $\mathrm{H}, \mathrm{O}$, and $\mathrm{Sr}$ isotopic compositions in order to interpret origin of salinity and geochemical evolution of brine compositions in this evaporite- and shale-poor cratonic basin. Although chloride concentrations range from 2000 to 137,000 $\mathrm{mg} / \mathrm{L}, \mathrm{Cl} / \mathrm{Br}$ ratios $(291 \pm 18)$ are consistent with those of seawater or seawater evaporated short of halite saturation $(\mathrm{Cl} / \mathrm{Br}=292)$. Thus, during Silurian-Devonian time, subaerially evaporated, penesaline brine entered the subsurface where it was chemically modified through brine-rock interactions. Cation/Br ratios and mineralogy of associated strata indicate that $\mathrm{Na}$ and $\mathrm{K}$ were depleted through interaction with clay minerals, $\mathrm{Ca}$ was enriched and $\mathrm{Mg}$ depleted by dolomitization, and $\mathrm{Sr}$ was enriched as a result of $\mathrm{CaCO}_{3}$ recrystallization and dolomitization. Although significant dilution of the modified brine with meteoric water is supported by $\delta \mathrm{D}-\delta^{18} \mathrm{O}$ covariance, original marine waters have not been completely expelled from Silurian-Devonian strata. Hydrogen and oxygen isotopes exhibit covariant relations with cation and anion concentrations, implying that isotopic exchange between $\mathrm{H}_{2} \mathrm{O}$ and minerals has not greatly influenced the $\delta \mathrm{D}-\delta^{18} \mathrm{O}$ trend. Brine ${ }^{87} \mathrm{Sr} /{ }^{86} \mathrm{Sr}$ ratios range from 0.7092 to 0.7108 ; when these ratios are plotted versus $1 / \mathrm{Sr}$, a two-component mixing trend is suggested, although $\mathrm{Sr}$ concentrations have experienced local diagenetic modification. A ${ }^{87} \mathrm{Sr}$-enriched fluid may have accompanied petroleum migration from New Albany shales into adjacent Silurian-Devonian carbonates where it mixed with remnant evaporated seawater. This event probably preceded the influx of meteoric water, as $\delta \mathrm{D}$ and $\delta^{18} \mathrm{O}$ are not correlated with $\mathrm{Sr}$ isotopic compositions of formation waters.
\end{abstract}

\section{INTRODUCTION}

THE ORIGIN OF WATER AND solutes in sedimentary basin brines remains a controversial aspect of sedimentary and aqueous geochemistry. The Illinois basin in particular is enigmatic because of the presence of extremely saline brines in what is an unusually evaporite- and shale-poor basin. Furthermore, hydrologic modeling (BETHKE, 1986) suggests that warm, metal-rich brincs from dccp in the basin were transported to basin margins by gravity-driven fluid flow, emplacing MVT ore deposits. The present paper focuses on the isotopic and elemental chemistry of formation waters from Silurian-Devonian strata in the Illinois basin. Such integrated data sets, heretofore unavailable in the basin, suggest that remnant marine fluids may play a significant role for both solutes and $\mathrm{H}_{2} \mathrm{O}$ molecules, implying that if gravity-driven recharge occurred in this basin it was insufficient to completely expel brines within these strata.

CLAYTON et al. (1966) carried out hydrogen and oxygen isotope analyses of waters from four sedimentary basins, including the Illinois basin, located at different latitudes in North America. Variation in deuterium content of the $\mathrm{H}_{2} \mathrm{O}$ molecules was much greater between basins than within each basin, and $\delta \mathrm{D}$ values generally matched the value for local meteoric water. These authors concluded that original marine water molecules in each basin had been expelled and replaced by meteoric water, while the dissolved solids had been retained. As the sedimentary section of the Illinois basin contains no known bedded halite and only a small amount of anhydrite, GRAF et al. (1966) concluded that salinity was achieved by shale-membrane filtration of original seawater. Thus, Illinois basin brines were interpreted as meteoric water that had been isotopically altered to various degrees, in terms of hydrogen by membrane filtration (GRAF ct al., 1965) and in terms of oxygen by equilibration with carbonate minerals (CLAYTON et al., 1966).

More recently, serious concerns regarding the effectiveness of shale-membrane filtration as a brine-forming mechanism have been raised by many workers (summarized by HANOR, 1983). Vertical differences in hydraulic head in the deeper rocks of the Illinois basin today are totally inadequate to drive membrane filtration (BOND, 1972). GRAF (1982) concluded that rapid sedimentation of fine-grained materials produced overpressuring which decayed after uplift of the basin, the subsurface brines retaining chemical and isotopic evidence of an carlicr period of membrane filtration. However, BETHKE (1986), using numerical modeling techniques to constrain basin hydrodynamics, determined that because of slow burial rates and low shale content the Illinois basin was not overpressured during its compaction, and he suggested that halite dissolution could be responsible for high salinities of formation waters.

Infiltration of subaerially evaporated seawater (CARPENTER, 1978) had not been considered as an explanation for the high salinities of Illinois basin brines, probably because the H-O isotope data of CLAYTON et al. (1966) demonstrate that the brines are isotopically dissimilar to seawater. However, it is now possible to interpret the $\delta \mathrm{D}-\delta^{18} \mathrm{O}$ trend of basin waters as a product of mixing between meteoric water and isotopically altered seawater, the seawater alteration being 
due either to subsurface water-rock interaction (HANOR, 1983 ) or to subaerial evaporation (KNAUTH and BEENAS, 1986).

Prior interpretations of the origin and evolution of Illinois basin brines have been based on samples and analytical data gathered nearly 30 or more years ago by the Illinois State Geological Survey, summarized in MEENTS et al. (1952) and in GRAF et al. (1966). A compendium of major and minor element analyses from the Indiana portion of the basin, compiled from 1958 to 1972 , was recently published by the Indiana Geological Survey (KELLER, 1983). As a result of a recent and continuing $\mathrm{Sr}$ isotope study of basin waters (STUEBER ct al., 1987), a large suite of new samples has been collected on which complete chemical and Sr isotopic analyses have been obtained. New and improved analytical techniques enable us to report minor and trace element data not available in previous studies, which may provide additional interpretive insight. Specifically, chloride-bromide relations can indicate sources of dissolved salts in formation waters, and cationbromide relationships may reveal the nature of diagenetic modifications in the subsurface (RITTENHOUSE, 1967; CARPENTER, 1978; DAS et al., 1990). An earlier publication (WALTER et al., 1990) addressed Br-Cl-Na systematics of waters from Ordovician through Pennsylvanian reservoirs in the basin and indicated that the overall $\mathrm{Cl}$ budget of basin waters appears more significantly influenced by retention of subaerially evaporated seawater than by halite dissolution. The $\mathrm{Br}-\mathrm{Cl}-\mathrm{Na}$ systematics as well as the $\mathrm{Sr}$ isotope systematics of Mississippian and Pennsylvanian formation waters are distinct from those of waters from Ordovician through Devonian reservoirs. These two segments of the stratigraphic section are separated by the New Albany Shale Group, considered to be the major petroleum source rock in the basin (BARRows and CiJJFF, 1984).

Major, minor, and trace element analyses of 51 formationwater samples from Silurian and Devonian reservoir rocks are presented here, along with $\mathrm{H}, \mathrm{O}$, and $\mathrm{Sr}$ isotope analyses of some selected samples. These new data are integrated with previously reported Sr isotopic analyses (STUEBER et al., 1987) to interpret the origin and chemical evolution of waters in this portion of the stratigraphic section.

\section{GEOLOGICAL SETTING}

The Illinois basin is an oval-shaped intracratonic basin located in Illinois, western Kentucky, and southwestern Indiana (Fig. 1). It initially formed during Paleozoic time by mechanical subsidence associated with rifting, followed by a period of thermal subsidence (HEIDLAUF et al., 1986). Late Cambrian through Pennsylvanian sediments reach a maximum present thickness of about $4.3 \mathrm{~km}$ in southern Illinois (WILLMAN et al., 1975) and probably exceed $6 \mathrm{~km}$ in thickness in portions of western Kentucky (BARROwS and CLUFF, 1984). The basin was open to the south throughout most of its development, but uplift of the Pascola arch resulted in closure sometime between the Pennsylvanian and Late Cretaceous (BUSCHBACH and ATHERTON, 1979; BETHKE, 1986).

The formation-water samples were collected within the state of Illinois (Fig. 1), where Cambrian and Ordovician sediments are dominated by carbonates and mature quartz arenites, and Silurian through middle Mississippian (Valmeyeran) sediments are almost entirely carbonates. The Maquoketa and New Albany groups are the only significant shale units in this portion of the stratigraphic section. Upper Mississippian (Chesterian) and Pennsylvanian strata consist of cyclic, interbedded sandstones, shales, and limestones, marking a change in environment and style of sediment deposition. Minor evaporites, consisting of gypsum and/or anhydrite, have been found in some Mississippian and Ordovician carbonate strata.

The Silurian and Devonian water samples were obtained from 30 oil fields (Fig. 1) producing from 9 reservoirs that are located stratigraphically below the New Albany Shale Group (Fig. 2). Only 2 of the 51 samples are from quartz sandstone reservoirs (Hardin and Dutch Creek); the remainder are from carbonate reservoirs. Carbonate strata within the Hunton Limestone Megagroup (SWANN and WILLMANN, 1961) have been dolomitized to varying degrees. Silurian carbonates are almost entirely dolomite in the northern portion of Illinois, whereas they are largely limestone to the south (WILLMAN et al., 1975). Devonian carbonates range from pure limestones to pure dolomites. None of the fields sampled had been subjected to waterflood operations for secondary petroleum recovery prior to sample collec-
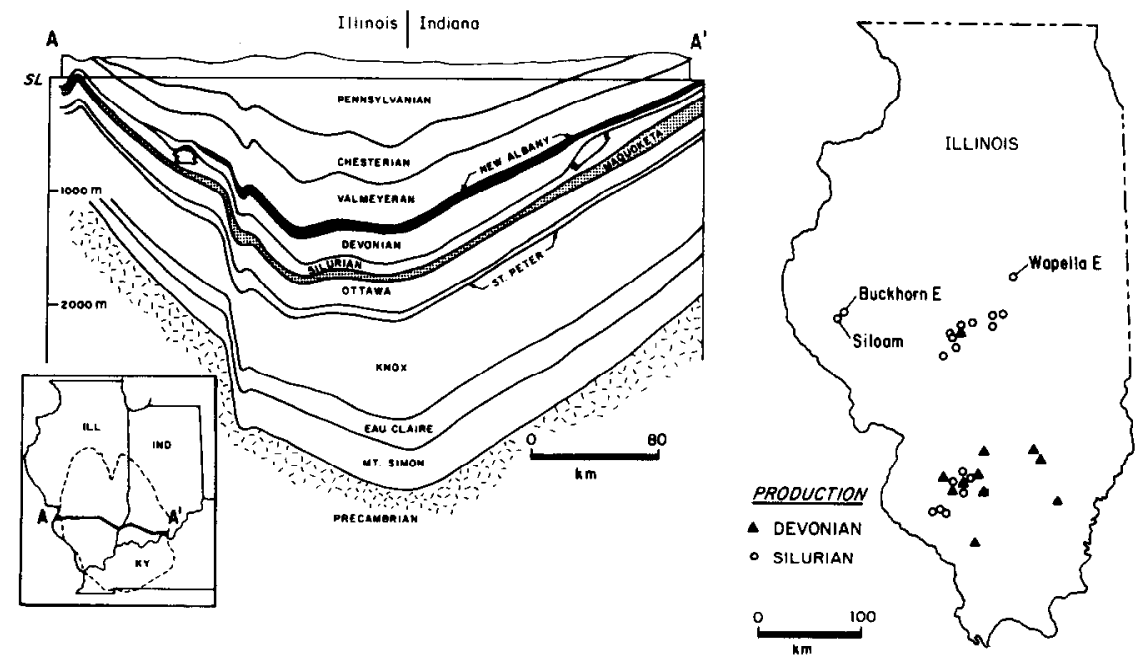

FIG. 1. The Illinois basin (inset) in the mid-continent region of the USA, an east-west subsurface cross-section, and locations of oil fields from which formation-water samples were collected. The Mt. Simon and Eau Claire formations are Cambrian, the Knox Megagroup is Upper Cambrian-Lower Ordovician, and the Ottawa Megagroup is Middle Ordovician; the Valmeyeran Series is Middle Mississippian, and the Chesterian Series is Upper Mississippian. Modified from SWANN (1967). 


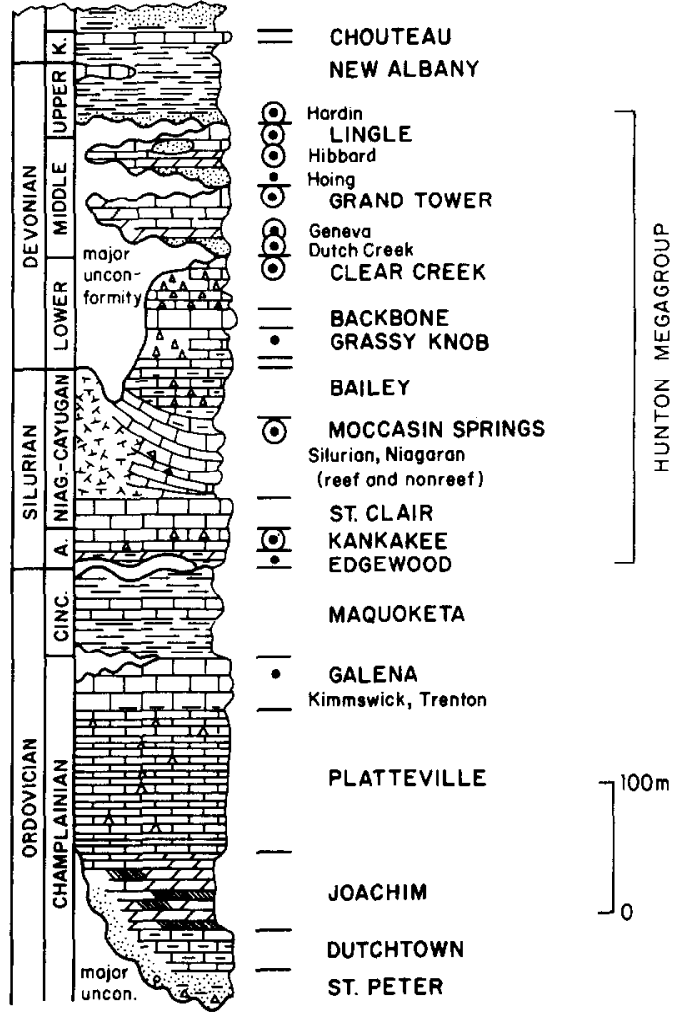

FIG. 2. Generalized geological column of Ordovician, Silurian, and Devonian strata in southern Illinois. Oil and gas pay zones are indicated by large dots; circled dut indicates analyzed formation water from the pay zone. Formation names are in capitals. From an Illinois State Geological Survey column, originally prepared by D. H. SWANN.

tion. MEENTS et al. (1952) showed that the lowest salinities are found near the margins of the basin and that total dissolved solids in water from a particular formation increase downdip toward the center of the basin. Salinities of water samples (Table 1) range from 3.9 to $223.2 \mathrm{~g} / \mathrm{L}$, and are consistent with these structure-depth relationships. Illinois basin waters are generally slightly depleted in $\mathrm{Na}$, strongly depleted in $\mathrm{K}, \mathrm{Mg}$, and $\mathrm{SO}_{4}$, and noticeably enriched in Ca rclative to seawater (HANOR 1979, 1983).

\section{ANALYTICAL METHODS AND RESULTS}

Most water samples analyzed in this study are from a larger suite collected during the period 1984-1988. Sampling procedures and preliminary treatment are described in STUEBER et al. (1987). All samples were passed through a $0.45 \mu \mathrm{m}$ filter, acidified to $\mathrm{pH}<2$ with Ultrex concentrated $\mathrm{HNO}_{3}$, and stored in polyethylene bottles. Fifty-one samples were analyzed for concentrations of major, minor, and trace elements (Table 2) by inductively coupled plasma-atomic emission spectrometry (ICP-AES) using a Leeman Labs Plasma-Spec III instrument. Precision of the analyses ranges from $\pm 1 \%$ for $\mathrm{Sr}$ to $\pm 7 \%$ for $\mathrm{K}$, based upon replicate analyses. Chloride, bromide, and $\mathrm{SO}_{4}$ concentrations were measured on a Dionex $4000 \mathrm{i}$ series ion chromatograph with AS2 and AS5 columns and suppressed conductivity detection. Precision of anion analyses is $\pm 1 \%$ for $\mathrm{Cl}$ and $\mathrm{SO}_{4}$, and $\pm 3 \%$ for $\mathrm{Br}$. Analyses of some subsamples that had not been treated with $\mathrm{HNO}_{3}$ yielded results identical to those for acidified samples.

Strontium isotope ratios (STUEBER et al., 1987) are included in Table 2, along with analyses of 14 samples which had not been reported previously. The additional samples, after separation of $\mathrm{Sr}$ by cation exchange chromatography, were analyzed at Washington University according to procedures described in PoPP et al. (1986). The mass spectrometer used is a VG Micromass 354 instrument which has three independent Faraday cups for simultaneous ion collection. Eight of the samples were analyzed in triple-collector mode, for which the analytical error in ${ }^{87} \mathrm{Sr} /{ }^{86} \mathrm{Sr}$ ratios is $\pm 0.00002(2 \sigma)$; others were run in single-collector mode with an analytical error of \pm 0.00003 . Analytical uncertainty for $\mathrm{Sr}$ isotope ratios in Table 2 , including those reported previously, is \pm 0.00006 or better, and ratios have been adjusted to the conventional value of 0.71014 for ${ }^{87} \mathrm{Sr} /$ ${ }^{86} \mathrm{Sr}$ in NBS-987.

The best evaluation of the reproducibility of the chemical and $\mathrm{Sr}$ isotope analyses, including sample collection and instrumental measurements, can be obtained by inspection of data for replicate formation-water samples collected from a designated test well in Tilden field (Table 3 ). Water from this well was sampled on a yearly basis between 1984 and 1988. Although concentrations of $\mathrm{SO}_{4}$ and trace elements exhibit variability significantly greater than analytical precision, other parameters do not.

A small set of formation-water samples was collected in 1988 for hydrogen and oxygen isotope analyses. A single sample was obtained from each of 12 oil fields producing from Silurian and Devonian reservoirs. Samples from these fields, which are widely distributed in central and southern Illinois, had been included in the larger suite of analyzed samples. In a few cases it was impossible to sample a well from which an earlier sample had been collected; in such cases the sample numbers in Table 2 indicate that an alternate well was sampled. Untreated water samples, obtained at the wellhead, were collected in glass bottles which were filled to overflowing and capped with air-tight lids. The samples were analyzed at Arizona State University, where oxygen isotope ratio variations were determined using the standard $\mathrm{CO}_{2}$ equilibration method (EPSTEIN and MAYEDA, 1953). Analyses were corrected for the effects of brine chemistry using the equation of SOFER and GAT (1972). The heated capillary method (KNAUTH and BEEUNAS, 1986) was used for hydrogen isotope analysis. Results (Table 2) are reported in concentration units as permil deviations from the SMOW standard (CRAIG, 1961). The probable errors are $\pm 0.2 \%$ for $\delta^{18} \mathrm{O}$ and $\pm 2 \%$ for $\delta \mathrm{D}$.

\section{CHLORIDE-BROMIDE RELATIONS: SUBAERIAL EVAPORATION OF SEAWATER}

During initial evaporation of seawater, both $\mathrm{Cl}$ and $\mathrm{Br}$ behave conservatively and increase in concentration while the $\mathrm{Cl} / \mathrm{Br}$ ratio remains constant at the normal seawater value (CARPENTER, 1978; MCCAFFrEY et al., 1987). As halite and other chloride minerals are precipitated, $\mathrm{Br}$ preferentially remains in solution; the $\mathrm{Cl} / \mathrm{Br}$ ratio of the residual brine decreases progressively, and each mineral develops a characteristic elevated $\mathrm{Cl} / \mathrm{Br}$ ratio. Differences between $\mathrm{Cl} / \mathrm{Br}$ ratios of evaporating seawater and those of evaporite minerals provide the theoretical basis for distinguishing between formation waters that are remnant evaporite brines and those which have formed in the subsurface by simple congruent dissolution of evaporite minerals (RITTENHOUSE, 1967; CARPENTER, 1978).

Recrystallization of halite preferentially rclcases $\mathrm{Br}$ to solution (LAND and PREZBINDOWSKI, 1981; LAND et al., 1988), a process that has been supported by experimental work (WILSON and LONG, 1984) and by theoretical considerations (STOESSEL and CARPENTER, 1986). Thus, incongruent dissolution of evaporite minerals may produce formation waters with $\mathrm{Cl} / \mathrm{Br}$ ratios that could lead to ambiguous or erroneous interpretations. Whatever the nature of the $\mathrm{Cl} / \mathrm{Br}$ ratios acquired by brines, whether through subaerial evaporation or subsurface interaction with evaporite deposits, they are subsequently preserved for interpretation because these anions generally do not participate in diagenetic reactions with other minerals. 
Table 1. Formation-water samples and related information

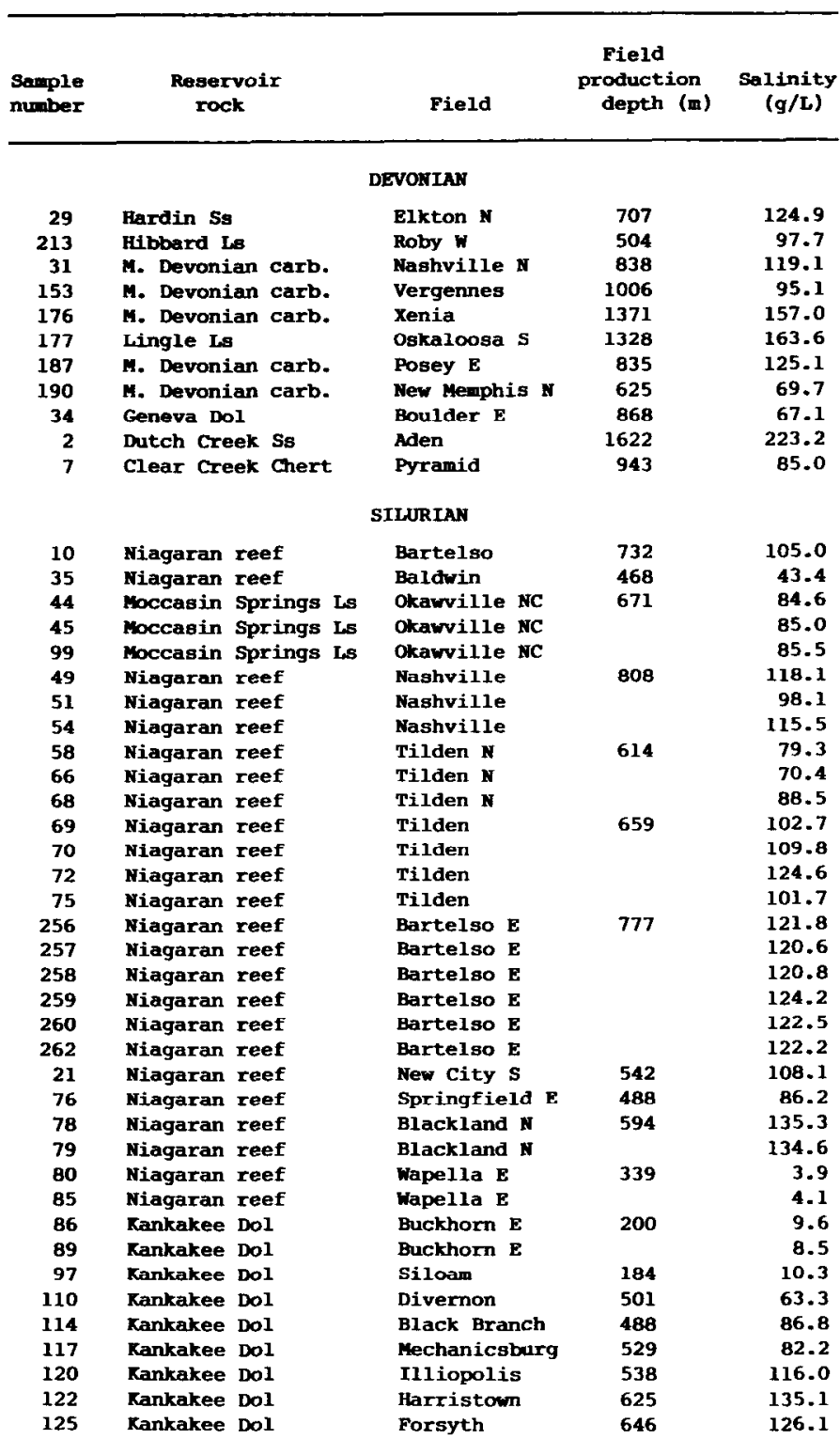

CARPENTER (1978) derived evolutionary trends for concentrations of major ions relative to $\mathrm{Br}$ in evaporating seawater, based on experiments of ZHEREBTSOVA and VOLKOVA (1966). These trends have recently been supported by field measurements (MCCAFFREY et al., 1987). Comparison of formation-water compositions with evaporation trends for modern seawater is justified because the composition of seawater has remained more or less constant since Cambrian time (Holland, 1978; Holser, 1979; DAS et al., 1990). Chloride-bromide relations in 51 formation-water samples from Silurian and Devonian strata in the Illinois basin are presented in Fig. 3. Silurian and Devonian data have been grouped because samples are all from reservoirs within the Hunton Limestone Megagroup. Based on Sr isotope relations, STUEBER et al. (1987) suggested that waters from Silurian and Devonian strata in the basin form a single hydrological system.
Chloride-bromide relations (Fig. 3a) generally show a close correspondence with the seawater evaporation trajectory and its extension below $\mathrm{Br}$ levels of seawater, the latter representing dilution with meteoric water. The five samples that are considerably more dilute than seawater are from three oil fields located near the northern perimeter of the basin (Fig. 1). Despite their low $\mathrm{Cl}$ and $\mathrm{Br}$ contents, these samples fall relatively close to the conservative dilution line for seawater with pure water (Fig. 3a). However, other ionic components in these samples are more profoundly affected by local water-rock interaction than by simple mixing with highly saline brines.

Silurian-Devonian formation waters more saline than seawater correlate very well with the seawater evaporation trajectory prior to halite prccipitation (Fig. $3 b$ ). The mean $\mathrm{Cl} /$ $\mathrm{Br}$ ratio for these 46 samples is $291 \pm 18$, compared with the normal seawater value of 292 (RILEY and CHESTER, 1971). 
Table 2. Chemical and isotopic analyses of formtion-water samples (concentrations in mg/L)

\begin{tabular}{|c|c|c|c|c|c|c|c|c|c|c|c|c|c|c|c|c|c|}
\hline Sanple & Na & $\mathrm{Ca}$ & $\mathbf{H g}$ & $\mathbf{K}$ & Sx & Cl & Br & $\mathrm{SO}_{4}$ & $\mathbf{s i}$ & B & $\mathbf{L i}$ & $\mathbf{B a}$ & $\mathrm{Fe}$ & In & $\delta^{18} 0 \%$ & $\delta D^{\circ} \%$ & ${ }^{87}{ }_{\mathrm{Sr} /}{ }^{86} \mathrm{Sr}$ \\
\hline \multicolumn{18}{|c|}{ DEVONIAN } \\
\hline 29 & 39000 & 5510 & 2110 & 246 & 337 & 77320 & 249 & 54 & 1.23 & 7.24 & - & 4.93 & 19.1 & 1.61 & - & - & 0.70972 \\
\hline 213 & 31500 & 4020 & 1570 & 375 & 225 & 59660 & 212 & 120 & 7.85 & 4.85 & 9.40 & - & 3.66 & 1.22 & - & - & 0.71028 \\
\hline 31 & 36600 & 5860 & 2270 & 228 & 393 & 73460 & 235 & nd & 5.06 & 7.24 & - & 29.3 & 0.37 & 1.67 & - & - & 0.70971 \\
\hline 153 & 30900 & 3.390 & 1700 & 412 & 369 & 58010 & 215 & 10 & 7.51 & 13.0 & - & 66.5 & 1.74 & 0.18 & - & - & 0.70955 \\
\hline 176 & 52100 & 6600 & 1510 & 542 & 260 & 94010 & 297 & 1647 & 8.04 & 11.9 & - & 0.67 & 0.42 & 0.90 & +0.1 & -18 & 0.70996 \\
\hline 177 & 51200 & 9600 & 2430 & 1270 & 243 & 97220 & 397 & 1190 & 7.26 & 20.4 & 22.9 & - & 0.29 & 0.16 & - & - & 0.70961 \\
\hline 187 & 38600 & 6310 & 2250 & 508 & 393 & 76690 & 250 & nd & 3.30 & 7.44 & 19.9 & - & 17.2 & 1.26 & - & - & 0.70991 \\
\hline $187 \pi$ & 36400 & 6000 & 2110 & 576 & 379 & 75960 & 264 & 70 & - & - & - & - & - & - & -0.9 & -24 & 0.70990 \\
\hline 190 & 22400 & 2790 & 1180 & 148 & 291 & 42610 & 151 & 127 & 7.20 & 4.53 & 13.3 & - & 0.18 & 0.16 & - & - & 0.70931 \\
\hline $190 \mathrm{~A}$ & 16300 & 1800 & 792 & 108 & 186 & 30160 & 114 & 42 & - & - & - & - & - & - & -3.7 & -35 & 0.70936 \\
\hline 34 & 21600 & 2400 & 960 & 436 & 177 & 41310 & 162 & 25 & B. 25 & 11.0 & - & 16.1 & 0.31 & 0.11 & - & - & 0.70978 \\
\hline 2 & 68200 & 12150 & 2390 & 1870 & 431 & 136900 & 470 & 72.7 & 7.68 & 52.6 & - & 1.11 & 7.40 & 0.35 & - & - & 0.70962 \\
\hline 7 & 26700 & 2900 & 1190 & 325 & 212 & 53380 & 185 & 72 & 7.56 & 13.6 & - & 7.74 & 2.84 & 0.16 & - & - & 0.71007 \\
\hline \multicolumn{18}{|c|}{ SILURIAN } \\
\hline 10 & 30900 & 4630 & 2030 & 289 & 932 & 65840 & 216 & 162 & 6.80 & 6.73 & - & 4.22 & 0.94 & 0.15 & - & - & 0.70924 \\
\hline 35 & 14100 & 980 & 760 & 141 & 103 & 27220 & 89 & 6 & 3.08 & 5.15 & - & 6.25 & 0.24 & 0.51 & $\ldots$ & - & 0.71070 \\
\hline 44 & 26600 & 3470 & 1610 & 173 & 577 & 51960 & 188 & $\mathbf{B}$ & 6.56 & 5.15 & - & 20.1 & 0.30 & 0.17 & - & - & 0.70922 \\
\hline 45 & 26800 & 3470 & 1610 & 159 & 504 & 52230 & 184 & nd & 6.57 & 5.34 & - & 19.4 & 0.31 & 0.15 & - & - & 0.70925 \\
\hline 99 & 25800 & 3810 & 1710 & 260 & 541 & 53140 & 197 & nd & 6.51 & 6.15 & - & 18.9 & 0.31 & 0.18 & - & - & 0.70937 \\
\hline 49 & 35900 & 6230 & 2010 & 513 & 160 & 71370 & 232 & 1706 & 5.10 & 9.35 & - & 0.39 & 0.44 & 0.13 & -0.7 & -21 & 0.70981 \\
\hline 51 & 30500 & 4530 & 1650 & 369 & 177 & 59750 & 189 & 934 & 6.43 & 7.03 & - & 0.55 & 1.01 & 0.22 & - & - & 0.70970 \\
\hline 54 & 35100 & 5830 & 2050 & 496 & 215 & 70580 & 235 & 925 & 7.32 & 10.3 & - & 0.99 & 1.68 & 0.20 & - & - & 0.70964 \\
\hline 58 & 25300 & 3290 & 1530 & 188 & 193 & 48530 & 170 & 129 & 6.51 & 5.21 & - & 1.15 & 2.57 & 1.33 & - & - & 0.70988 \\
\hline $58 A$ & 26700 & 4040 & 1560 & 260 & 202 & 50520 & 186 & 787 & - & - & - & - & - & - & -1.8 & -27 & 0.70995 \\
\hline 66 & 22000 & 3210 & 1130 & 193 & 145 & 42910 & 147 & 649 & 5.58 & 5.41 & - & 0.78 & 44.7 & 2.03 & - & - & 0.71001 \\
\hline 68 & 25800 & 5380 & 1600 & 230 & 172 & 53930 & 179 & 1197 & 8.78 & 5.80 & - & 0.53 & 15.7 & 0.99 & - & - & 0.70984 \\
\hline 69 & 31300 & 5140 & 1980 & 278 & 284 & 62780 & 210 & 678 & 5.04 & 7.27 & - & 0.72 & 0.42 & 0.24 & -1.6 & -24 & 0.71007 \\
\hline 70 & 33700 & 5420 & 1970 & 274 & 287 & 67350 & 219 & 603 & 5.88 & 6.70 & - & 0.91 & 0.46 & 0.20 & - & - & 0.70992 \\
\hline 72 & 37600 & 6630 & 2190 & 355 & 321 & 76750 & 267 & 445 & 3.91 & 5.88 & - & 0.93 & 0.40 & 0.31 & - & - & 0.71011 \\
\hline 75 & 31100 & 4830 & 1620 & 299 & 317 & 62890 & 219 & 413 & 6.19 & 5.84 & - & 1.37 & 1.66 & 0.19 & - & - & 0.70998 \\
\hline 256 & 36030 & 6970 & 2490 & 621 & 204 & 75200 & 255 & 1367 & 7.11 & 11.3 & 20.7 & - & - & - & - & - & 0.70958 \\
\hline 257 & 36100 & 6520 & 2420 & 608 & 276 & 74400 & 259 & 687 & 6.16 & 11.0 & 17.0 & - & - & - & - & - & 0.70954 \\
\hline 258 & 36950 & 6380 & 2440 & 503 & 328 & 73900 & 258 & 693 & 6.15 & 9.68 & 19.7 & - & - & - & - & - & 0.70951 \\
\hline 259 & 37400 & 6810 & 2440 & 663 & 228 & 76400 & 262 & 1133 & 6.43 & 10.7 & 15.1 & - & - & - & - & - & 0.70964 \\
\hline 260 & 37150 & 6390 & 2430 & 632 & 345 & 75300 & 252 & 444 & 6.39 & 12.1 & 15.0 & - & - & - & - & - & 0.70950 \\
\hline 262 & 34250 & 9090 & 2380 & 629 & 297 & 75300 & 230 & 93 & 11.7 & 8.96 & 15.8 & - & - & - & - & - & 0.70948 \\
\hline 21 & 33100 & 4670 & 1550 & 379 & 183 & 66850 & 224 & 1139 & 6.72 & 4.13 & - & 0.49 & 0.83 & 0.34 & - & - & 0.71076 \\
\hline 76 & 27200 & 3450 & 1310 & 322 & 213 & 53470 & 198 & nd & 5.27 & 3.81 & - & 12.4 & 0.28 & 0.22 & -2.4 & -25 & 0.71032 \\
\hline 78 & 42900 & 5910 & 2110 & 440 & 265 & 82970 & 276 & 423 & 5.33 & 4.06 & - & 0.70 & 0.68 & 0.39 & - & - & 0.71012 \\
\hline 79 & 41800 & 5910 & 2070 & 419 & 259 & 83350 & 274 & 469 & 4.82 & 4.60 & - & 0.63 & 11.7 & 1.21 & +0.6 & -12 & 0.71004 \\
\hline 80 & 1550 & 38 & 22 & 23 & 1.9 & 2020 & 6.7 & 195 & 4.58 & 2.10 & - & 0.11 & 0.01 & 0.10 & - & - & 0.71010 \\
\hline 85 & 1610 & 50 & 24 & 24 & 2.3 & 2130 & 7.1 & 217 & 5.63 & 2.13 & - & 0.10 & 0.06 & 0.18 & -8.5 & -57 & 0.71005 \\
\hline 86 & 3840 & 55 & 49 & 26 & 7.0 & 5570 & 16.5 & $B$ & 4.13 & 1.77 & - & 4.02 & 0.03 & nd & - & - & 0.70952 \\
\hline 89 & 3310 & 100 & 72 & 40 & 6.5 & 4950 & 13.1 & 7 & 5.98 & 2.24 & - & 30.7 & 0.04 & nd & - & - & 0.70985 \\
\hline 97 & 4130 & 50 & 54 & 32 & 8.3 & 6010 & 17.5 & nd & 4.29 & 1.77 & - & 34.6 & 0.03 & nd & - & - & 0.70978 \\
\hline 110 & 20400 & 2170 & 990 & 249 & 145 & 39210 & 137 & nd & 5.67 & 3.77 & - & 25.2 & 0.25 & 0.17 & - & - & 0.71084 \\
\hline $110 \mathrm{~A}$ & 23000 & 2350 & 1130 & 296 & 171 & 41440 & 156 & nd & - & - & - & - & - & - & -3.0 & -29 & 0.71067 \\
\hline 114 & 27700 & 3550 & 1460 & 309 & 231 & 53340 & 199 & 7 & 5.22 & 3.86 & - & 3.18 & 0.30 & 0.15 & - & - & 0.71025 \\
\hline 117 & 26800 & 2950 & 1360 & 322 & 164 & 50450 & 182 & nd & 5.30 & 3.91 & - & 5.80 & 0.29 & 0.38 & -3.0 & -29 & 0.71031 \\
\hline 120 & 37400 & 4510 & 1990 & 424 & 223 & 71200 & 244 & nd & 3.60 & 4.16 & - & 4.83 & 0.35 & 0.30 & -0.9 & -21 & 0.71009 \\
\hline 122 & 43500 & 6030 & 2010 & 526 & $25 B$ & 82340 & 273 & 173 & 4.06 & 5.05 & - & 0.78 & 0.35 & 0.49 & - & - & 0.71026 \\
\hline 125 & 41000 & 5380 & 1810 & 481 & 241 & 76580 & 233 & 342 & 4.30 & 5.08 & - & 0.98 & 0.35 & 0.67 & - & - & 0.71025 \\
\hline
\end{tabular}

Formation waters that plot on the $\mathrm{Cl}-\mathrm{Br}$ seawater evaporation trajectory can be interpreted tentatively as ancient evaporite brines (HANOR, 1987; KNAUTH, 1988), although few subsurface waters actually fall on the trajectory (HANOR, 1987). Whereas $\mathrm{Cl}-\mathrm{Br}$ compositions of formation waters from most basins have apparently been affected by water-rock interactions, Silurian-Devonian waters from the Illinois basin represent one significant data set coinciding with the evaporation trajectory prior to halite saturation. Thus, on the basis of their $\mathrm{Cl}-\mathrm{Br}$ relations, these Silurian and Devonian formation waters may be interpreted as having originated from seawater that did not evaporate to the point of halite precipitation, consistent with the absence of any type of evaporite deposit in this portion of the stratigraphic section in the Illinois basin (Fig. 2).

Formation-water samples that fall on the $\mathrm{Cl}-\mathrm{Br}$ seawater evaporation trajectory prior to halite precipitation would not be displaced from the line through simple dilution with meteoric water or seawater after subaerial evaporation and concentration. Widespread distribution of data along the evaporation trajectory in Fig. 3b suggests that a conservative dilution process has subsequently affected these waters. The water sample with the highest $\mathrm{Cl}$ content $(136,900 \mathrm{mg} / \mathrm{L} \mathrm{Cl})$ suggests a minimum seven-fold concentration of seawater, 
Table 3. Replicate sampling and analysis of formation
waters from a single well in Tilden field

(element concentrations in $\mathrm{mg} / \mathrm{L}$ )

\begin{tabular}{lrrrrr}
\hline Collection Date & $9 / 14 / 84$ & $8 / 20 / 85$ & $10 / 25 / 86$ & $6 / 25 / 87$ & $9 / 09 / 88$ \\
\hline $\mathrm{Ma}$ & 31300 & 31300 & 31300 & 31500 & 31000 \\
$\mathrm{Ca}$ & 5160 & 5130 & 5150 & 5170 & 5090 \\
$\mathrm{Mg}$ & 1940 & 1950 & 1940 & 1950 & 1940 \\
$\mathrm{~K}$ & 271 & 274 & 269 & 271 & 305 \\
$\mathrm{Sr}$ & 284 & 286 & 284 & 283 & 283 \\
$\mathrm{Cl}$ & 62910 & 62930 & 62400 & 62960 & 62960 \\
$\mathrm{Br}$ & 202 & 212 & 219 & 215 & 201 \\
$\mathrm{SO}$ & 708 & 654 & 706 & 696 & 625 \\
$\mathrm{Si}$ & 4.39 & 1.93 & 6.11 & 6.32 & 6.45 \\
$\mathrm{~B}$ & 7.09 & 7.16 & 7.14 & 7.29 & 7.65 \\
$\mathrm{Ha}$ & 0.67 & 0.68 & 0.68 & 0.84 & 0.75 \\
$\mathrm{Fe}$ & 0.47 & 0.66 & 0.38 & 0.38 & 0.21 \\
$\mathrm{Hn}$ & 0.46 & 0.36 & 0.15 & 0.15 & 0.10 \\
$\mathrm{TOS}(\mathrm{g} / \mathrm{L})$ & 102.8 & 102.7 & 102.3 & 103.1 & 102.4 \\
$\mathrm{B7} \mathrm{Sr} /{ }^{86} \mathrm{Sr}$ & 0.71015 & 0.71009 & 0.71001 & 0.71008 & 0.71001 \\
\hline
\end{tabular}

representing approximately $75 \%$ of the evaporative concentration needed to reach halite saturation at 183,950 $\mathrm{mg} / \mathrm{L} \mathrm{Cl}$.

The Cl-Br relations in Fig. 3 are inconsistent with simple congruent dissolution of halite, which would yield values with extremely high $\mathrm{Cl} / \mathrm{Br}$ ratios. STOESSELL and CARPENTER (1986), observing that the $\mathrm{Br}$ content of freshly precipitated halite does not appear to be in thermodynamic equilibrium with the associated liquid, employed the concept of stoichiometric saturation to explain liquid control on the precipitation of halite. Incongruent halite dissolution as an approach to equilibrium is a feasible means of increasing the relative $\mathrm{Br}$ content of formation waters and thereby reducing their $\mathrm{Cl}$ / $\mathrm{Br}$ ratios compared to halite. However, it would seem fortuitous that such waters should acquire the $\mathrm{Cl} / \mathrm{Br}$ ratio of seawater over a significant range of $\mathrm{Cl}$ concentrations (Fig. $3 b$ ). The $\mathrm{Cl} / \mathrm{Br}$ ratio acquired by a formation water during incongruent dissolution of halite is very sensitive to $\mathrm{Br}$ content of original halite, rock/water ratio, and value chosen for the distribution coefficient for $\mathrm{Br}$ in halite. A strongly halitedominated system is required for incongruent halite dissolution to yield a formation water with the $\mathrm{Cl} / \mathrm{Br}$ ratio of seawater (STOESSELL and CARPENTER, 1986). Therefore, the salinity of Silurian-Devonian formation waters in the basin is most simply interpreted as the result of subaerial evaporation of seawater.

The thick evaporite sequences that characterize SilurianDevonian strata in the eastern Great Lakes region do not extend into the Illinois basin. Our interpretation that SilurianDevonian formation waters in the basin originated through seawater evaporation short of halite precipitation is consistent with the paucity of evaporite deposits throughout the stratigraphic section and with the absence of bedded halite. Ordovician carbonates contain anhydrite (SAXBY and LAMAR, 1957; STEVENSON et al., 1975), and bedded gypsum and anhydrite occur in a portion of the Mississippian St. Louis Limestone (Fig. 1; Valmeyeran Series) in Illinois (SAXBY and LAMAR, 1957), Indiana (MCGREGOR, 1954), and Kentucky (MCGRAIN and HELTON, 1964). However, according to BETHKE (1986) the only evidence of halide occurrence in the Illinois basin is found in occasional cubic casts.
Recent studies of Silurian-Devonian paleoenvironments in the Illinois basin (COBURN, 1986; WHITAKER, 1988) provide the potential for subaerial evaporation of seawater. According to these reconstructions, Illinois was situated on a gently dipping carbonate shelf or ramp along the western flank of a large basin. Reefs formed on this stable ramp across most of the proto-Illinois basin during the Silurian; regressing seas during the late Silurian and early Devonian subaerially exposed reef crests and terminated their growth. Lagoonal environments could have developed within this setting, restricting water circulation and leading to penesaline conditions. A Silurian-Devonian paleolatitude of about $25^{\circ} \mathrm{S}$ (VAN DER VOO, 1988) provided an appropriate subtropical climate for subaerial evaporation. Dense saline water forming in this type of environment could penetrate underlying sediments; progressive burial and compaction would then disperse the brine into other sedimentary units. Those who favor brine origin through halite dissolution point out that the volumes of surficially generated brines that could be buried with evaporite strata of negligible porosity are insufficient to account for the large volumes of existing saline formation waters (LAND and PREZBINDOWSKI, 1985; CASAS and LOWENSTEIN, 1989). This argument is not applicable in the Illinois basin, where seawater evaporation did not reach the point of forming significant evaporite strata and the penesaline water was underlain by porous sediments. Syndepositional loss of residual evaporite brines has been suggested for portions of the Gulf Coast and Alberta Basins (STOESSELL and MOORE, 1985; KHARAKA et al., 1987; and SPENCER, 1987).

\section{CATION-BROMIDE RELATIONS: CHEMICAL CHANGES IN THE SUBSURFACE}

Changes in the chemical composition of evaporated Silurian-Devonian seawater that have occurred as a result of diagenetic reactions in the subsurface are revealed by departures of formation-water compositions from cation-Br evaporation trends. Such relations for $\mathrm{Na}$ and $\mathrm{K}$ are shown in Fig. 4. Sodium concentrations tend to lie slightly below the seawater evaporation trajectory (Fig. 4a), forming a trend generally parallel to that line. Sodium concentrations have 

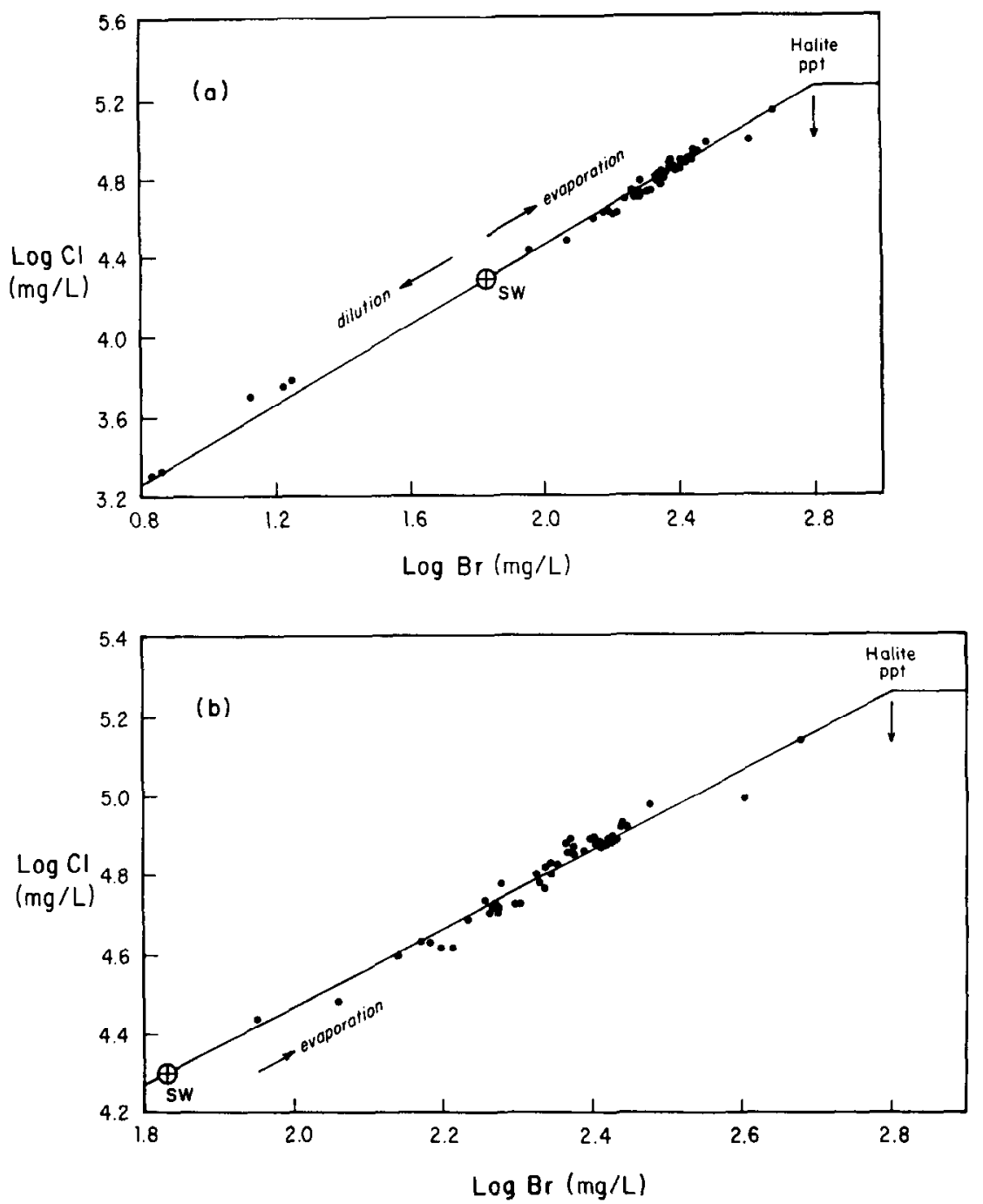

FIG. 3. (a) Cl-Br relations in 51 formation-water samples from Silurian and Devonian reservoirs in the Illinois basin (see Figs. 1 and 2). Seawater evaporation-dilution trajectory from CARPENTER (1978); SW indicates seawater composition. (b) Enlarged portion of (a), showing formation-water samples that are more saline than seawater.

been depleted on average by about $9 \%$, as indicated by a mean $\mathrm{Na} / \mathrm{Br}$ ratio of 148 compared with a value of 163 for seawater (Table 4). Potassium concentrations lie well below the seawater evaporation trajectory (Fig. 4b), indicating significant depletion of $\mathrm{K}$ in the subsurface. Although there is a considerable degree of scatter in the data points, reflecting variability in the extent of diagenetic interaction, the mean $\mathrm{K} / \mathrm{Br}$ ratio of 1.77 when compared with a seawater value of 6.12 yields an average $\mathrm{K}$ depletion of about $71 \%$ (Table 4 ).

Loss of $\mathrm{Na}$ from saline formation waters is frequently attributed to albitization of plagioclase feldspar (CARPENTER, 1978; LAND and PREZBINDOWSKI, 1981, 1985; LAND, 1987). CARPENTER (1978) suggested that $K$ loss from brincs is duc to reaction with low- $\mathrm{K}$ clay minerals such as kaolinite to produce $\mathrm{K}$-rich clays such as illite, as well as authigenic $\mathrm{K}$ feldspar. Potassium depletion in brines has also been attributed to formation of K-feldspar from albite (EGEBERG and AAGAARD, 1989). Feldspars, however, are not abundant in detrital sediments of the Illinois basin (POTTER and GLASS,
1958; POTTER, 1962; SWANN, 1967), which are principally shales and quartz sandstones. Silurian-Devonian strata, dominantly carbonates, contain only a few minor sandstone units (Fig. 2), and these are mature quartz arenites. Also, NESBITT $(1980,1985)$ found that Illinois basin formation waters from upper Mississippian and Pennsylvanian sandstone reservoirs are equilibrated with clay minerals but not with feldspars, which he ascribed to the much greater relative abundance of the clays. NESBITT (1985) proposed that $\mathrm{Na}$ contents of Mississippian and Pennsylvanian formation waters are controlled by mineral reactions involving clay minerals and calcite.

Concentrations of the divalent cations $\mathrm{Ca}, \mathrm{Mg}$, and $\mathrm{Sr}$ (Fig. 5) are apparently controlled primarily by diagenetic reactions between the formation waters and carbonates. Relations between $\mathrm{Ca}$ and $\mathrm{Br}$ (Fig. 5a) reveal large $\mathrm{Ca}$ enrichments relative to evaporated seawater. The mean $\mathrm{Ca} / \mathrm{Br}$ ratio of 21.7 (Table 4) indicates an average 3.5-fold Ca enrichment over evaporated seawater as a result of water-rock interactions. Mag- 

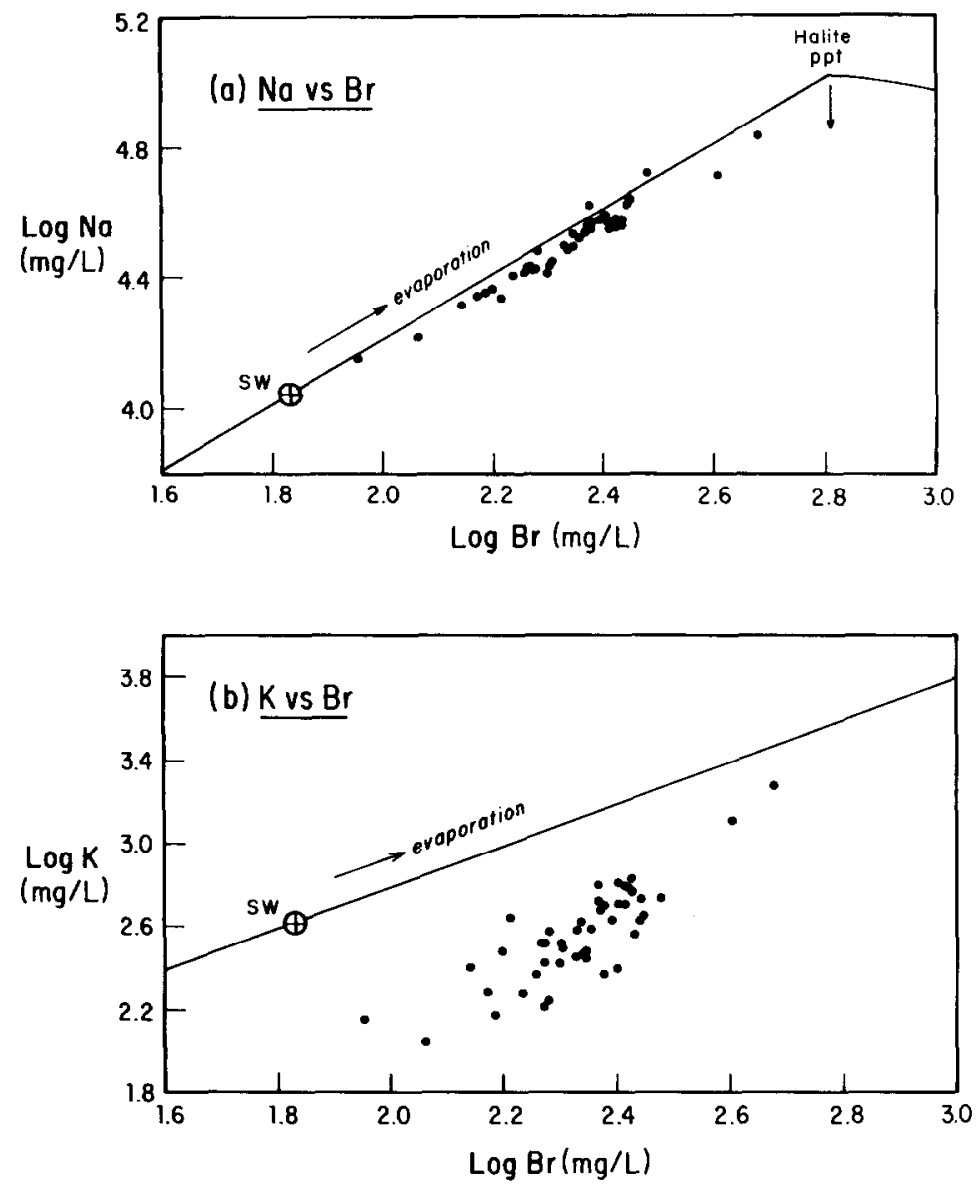

Fig. 4. (a) $\mathrm{Na}-\mathrm{Br}$ and (b) $\mathrm{K}-\mathrm{Br}$ relations in 46 formation-water samples from Silurian and Devonian reservoirs in the Illinois basin. Seawater evaporation trajectories from CARPENTER (1978); SW indicates seawater composition.

nesium-bromide relations in Fig. 5b show a complementary Mg depletion; $\mathrm{Mg}$ concentrations have been reduced on average by about $59 \%$ compared with evaporated seawater ( $\mathrm{Ta}-$ ble 4). Proponents of halite dissolution as a source of saline formation waters (LAND and PREZBINDOWSKI, 1981, 1985) invoke albitization of detrital plagioclase as a mechanism to elevate Ca concentrations, whereas other workers (CARPENTER, 1978; STOESSELL and MOORE, 1983, 1985) believe that dolomitization of limestone is more important. The paucity of detrital plagioclase in rocks of the Illinois basin and its virtual absence in the Hunton Megagroup, as well as the complementary behavior of $\mathrm{Ca}$ and $\mathrm{Mg}$ in formation waters

Table 4. Summary of chemical chenges in Silurian-Devunian formation waters through diagenetic processes (all ratios by weight)

\begin{tabular}{|c|c|c|c|c|}
\hline Ion & $\begin{array}{c}\text { Ion/Br } \\
\text { (Seawater) }\end{array}$ & $\begin{array}{c}\text { Ion/Br } \\
\text { (Fw. Waters) }\end{array}$ & $\begin{array}{c}\text { Enrichment } \\
\text { (Depletion) } \\
\text { Factor** }\end{array}$ & $\begin{array}{l}\text { Dominant } \\
\text { Diagenetic } \\
\text { Process }\end{array}$ \\
\hline $\mathrm{Cl}^{-}$ & 292 & $291 \pm 18$ & & \\
\hline $\mathrm{Na}^{+}$ & 163 & $148 \pm 9$ & 0.91 & $\begin{array}{l}\text { reaction with } \\
\text { clay minerals }\end{array}$ \\
\hline $\mathrm{x}^{+}$ & 6.12 & $1.77 \pm 0.63$ & 0.29 & $\begin{array}{l}\text { reaction with } \\
\text { clay minerals }\end{array}$ \\
\hline $\mathrm{Ca}^{2+}$ & 6.21 & $21.7 \pm 4.9$ & 3.49 & dolonitization \\
\hline $\mathrm{Hg}^{2+}$ & 19.5 & $8.07+1.21$ & 0.41 & dolomitiration \\
\hline$S r^{2+}$ & 0.12 & $1.32 \pm 0.68$ & 11.0 & $\begin{array}{c}\mathrm{CaCO}_{3} \text { recrystal } \\
\text { dolomitization }\end{array}$ \\
\hline
\end{tabular}

* Riley and chester, 1971

** (Fa. Waters)/( Seawater) 

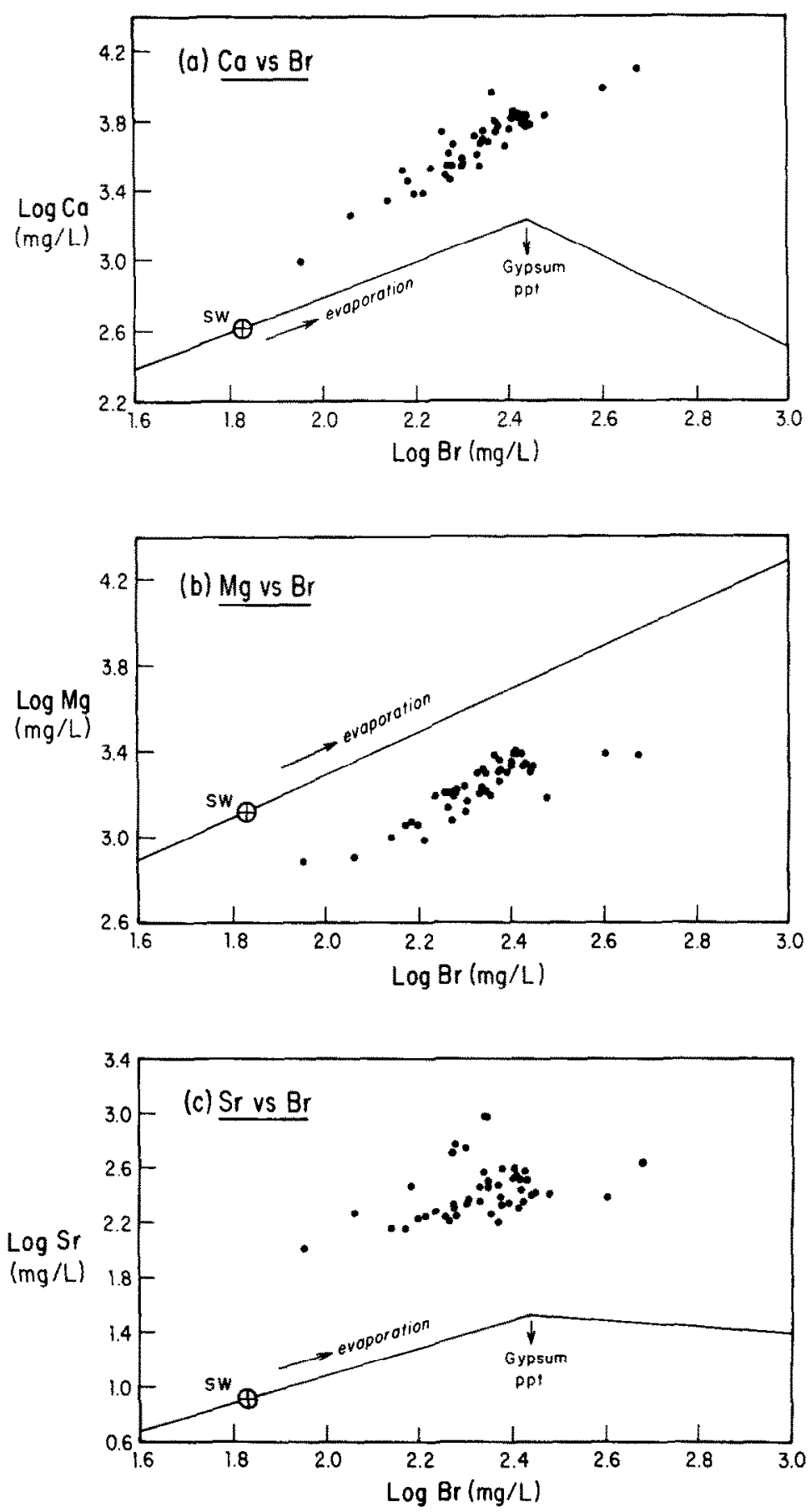

Frg. 5. (a) $\mathrm{Ca}-\mathrm{Br}$, (b) $\mathrm{Mg}-\mathrm{Br}$, and (c) $\mathrm{Sr}-\mathrm{Br}$ relations in 46 formation-water samples from Silurian and Devonian reservoirs in the Illinois basin. Seawater evaporation trajectories from CARPENTER (1978); SW indicates seawater composition.

produced largely from partially dolomitized carbonate strata support the latter point of view.

Strontium-bromide relations (Fig. 5c) show a significant enrichment in Sr concentrations over evaporated seawater. The mean $\mathrm{Sr} / \mathrm{Br}$ ratio of 1.32 (Table 4 ) reveals an average 11-fold enrichment in $\mathrm{Sr}$ subsequent to subaerial evaporation, indicating that nearly all the $\mathrm{Sr}$ in these formation waters has been acquired through diagenetic reactions. Although Sr may be contributed through dissolution and albitization of detrital feldspars (LAND, 1987), it seems more likely that most Sr has been derived by recrystallization and dolomitization of carbonate mincrals. On a molar basis, $\mathrm{Mg}$ depletion exceeds ( $\mathrm{Ca}$ $+\mathrm{Sr}$ ) enrichment by about $17 \%$, suggesting that other diagenetic reactions have affected these divalent cations. Magnesium in Illinois basin waters may be consumed in regrading partially weathered chlorite and by formation of chlorite from degraded illite (GRAF et al., 1966). Such reactions would not return $\mathrm{Ca}$ to solution and might account, at least in part, for 


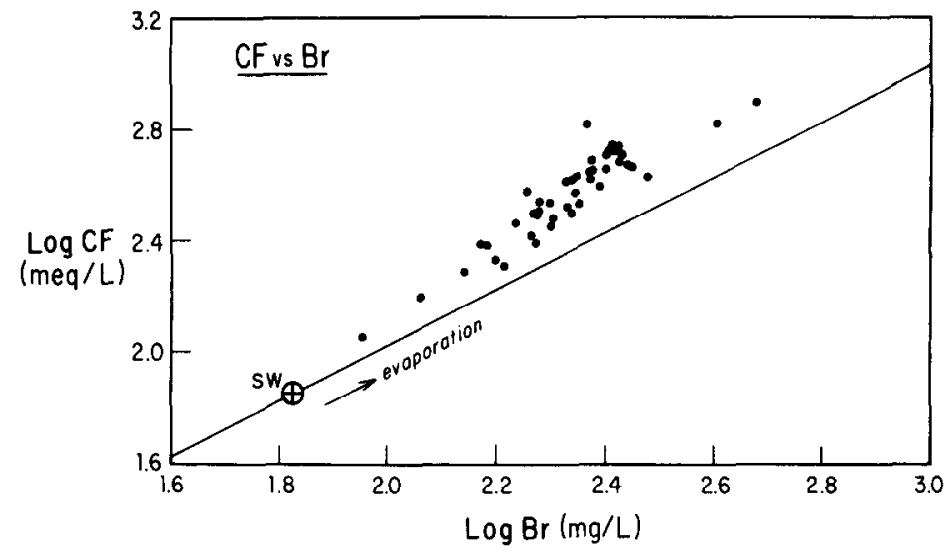

FiG. 6. Relations between Carpenter Function (CF; defined in text) and $\mathrm{Br}$ concentrations in 46 formation-water samples from Silurian and Devonian reservoirs in the Illinois basin. Seawater evaporation trajectory from CARPENTER (1978); SW indicates seawater composition.

the excess $\mathrm{Mg}$ depletion inferred here. On the other hand, some $\mathrm{Ca}$ and $\mathrm{Sr}$ have undoubtedly been lost through precipitation of gypsum or anhydrite, and also through precipitation of calcite following bacterial sulfate reduction. These reactions would not extract $\mathrm{Mg}$ and could explain the observed relations.

CARPENTER (1978) devised an approach to account for diagenetic reactions involving divalent cations and carbonate and sulfate minerals to deduce whether a brine originated from evaporation of seawater followed by such reactions or if the brine had a more complex origin. Additional complexities might include diagenetic reactions involving monovalent cations, silicate minerals, or halite. The quantity of divalent cations charge-balanced only by $\mathrm{Cl}$ was defined as the Carpenter Function (CF) by KNAUTH (1988):

$$
\mathrm{CF}=\mathrm{Ca}+\mathrm{Mg}+\mathrm{Sr}-\mathrm{SO}_{4}-\mathrm{HCO}_{3} \text { (in meq/L). }
$$

When this function is plotted versus $\mathrm{Br}$, evaporating seawater defines a trajectory unaffected by dolomitization, recrystallization or precipitation of $\mathrm{CaCO}_{3}$, or $\mathrm{CaSO}_{4}$ precipitation.
Carpenter Function-bromide relations in Silurian-Devonian formation waters and in evaporating seawater are illustrated in Fig. 6. Bicarbonate concentrations, which were not determined in the water samples, were not considered in calculating $\mathrm{CF}$ values. However, as pointed out by CARPENTER (1978), $\mathrm{HCO}_{3}$ concentrations in most brines are very low and are generally negligible relative to $\mathrm{Cl}$ concentrations. The data of GrAF et al. (1966) show that this is the case in Illinois basin waters. Formationwater data in Fig. 6 lie on a trend above the seawater evaporation trajectory, indicating enrichment in divalent cations or depletion in $\mathrm{Br}$ relative to evaporated seawater. Because $\mathrm{Cl}-\mathrm{Br}$ relations coincide with the seawater evaporation trajectory (Fig. 3b), these formation waters must have gained divalent cations by diagenetic reactions other than those accounted for by the Carpenter Function. Depletion of $\mathrm{Na}$ and $\mathrm{K}$ in these waters has been attributed to formation of sodic clays, illite, and authigenic K-feldspar from kaolinite. During these reactions hydrogen ions are

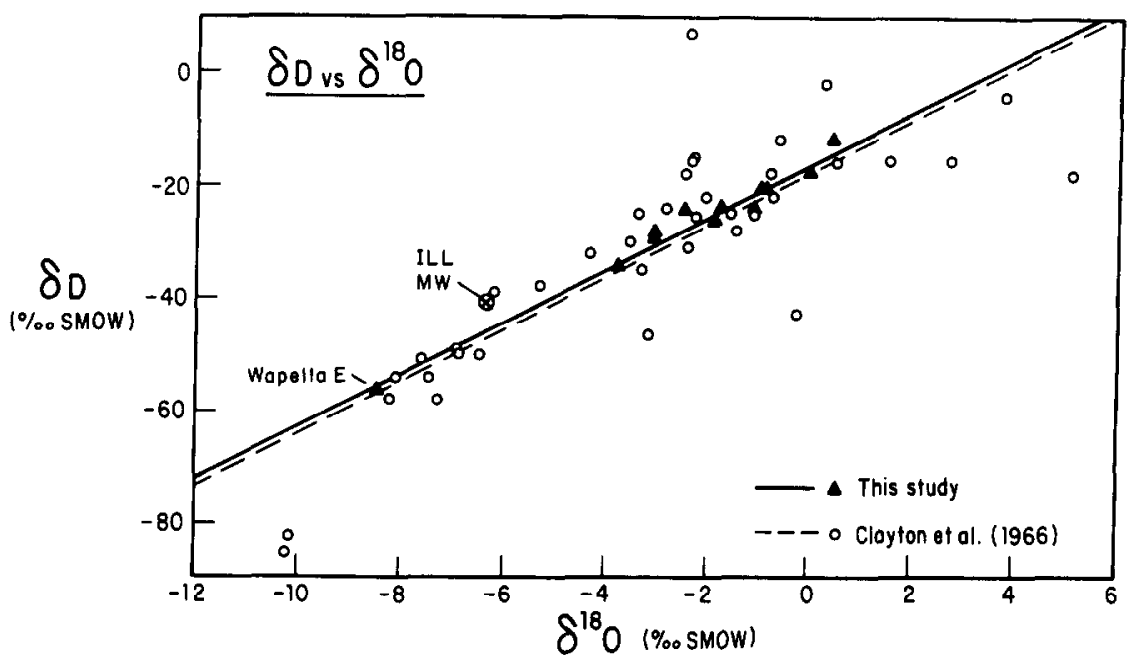

FIG. 7. Hydrogen-oxygen isotope compositions of formation waters from the Illinois basin, including 12 SilurianDevonian waters from this study and 38 samples from various reservoirs reported by CLAYTON et al. (1966). A regression line is shown for each set of data. ILL MW indicates the isotopic composition of present-day local meteoric water. 
released which are available to react with carbonate minerals, increasing the Carpenter Function value.

In summary, diagenetic modification of the chemistry of evaporated Silurian-Devonian seawater has been traced through relations between cations and $\mathrm{Br}$ anions in formation waters. Chloride and bromide concentrations were established by subaerial seawater evaporation short of halite precipitation. Relative to evaporated seawater, $\mathrm{Na}$ and $\mathrm{K}$ concentrations have been depleted through interactions with clay minerals, $\mathrm{Ca}$ has been enriched and $\mathrm{Mg}$ depleted by dolomitization of carbonates, and $\mathrm{Sr}$ has been enriched through $\mathrm{CaCO}_{3}$ recrystallization and dolomitization. Thus a K, Mg-rich brine formed by evaporation of seawater evolved through rockwater interactions into the $\mathrm{Na}-\mathrm{Ca}-\mathrm{Cl}$ brine.

\section{$\delta D-\delta^{18} O$ RELATIONS: MIXING WITH METEORIC WATER}

Widespread distribution of brine compositions along the $\mathrm{Cl}$-Br seawater evaporation trajectory (Fig. 3b) suggests that mixing of evaporated seawater with meteoric water and/or seawater has occurred. A conservative mixing event is also inferred by cation- $\mathrm{Br}$ trends in Figs. 4 and 5, which generally are linear and subparallel to the respective evaporation trajectories despite diagenetic modifications of cations. In addition, ionic concentrations generally increase with brine production depth, suggesting influx of dilute surface waters. Mixing of saline formation waters with dilute waters such as the samples encountered in the northern portion of the Illinois basin (data points less saline than seawater in Fig. 3a) would also yield apparently conservative element-element mixing relations. Although these dilute water samples have element/ $\mathrm{Br}$ ratios which differ substantially from more saline brines, the saline endmember would be the dominant lever in the mixing process.

Our $\delta \mathrm{D}$ and $\delta^{18} \mathrm{O}$ data (Table 2) and those of CLAYTON et al. (1966) are plotted in Fig. 7. Agreement between the two data sets is excellent. Greater scatter of the earlier data may reflect wider stratigraphic distribution of their samples and differences in sampling and analytical techniques. Regression lines do not pass through present-day local meteoric water, as they are strongly influenced by samples that are isotopically lighter than present meteoric water. One sample in this group is from our collection, a very dilute water from an oil field (Wapella E) located near the northern perimeter of the basin (Fig. 1). The isotopic composition of this water may have been influenced by Pleistocene glacial water, an explanation offered by CLAYTON et al. (1966) for the isotopically anomalous nature of two of their samples that are shown near the lower left corner of Fig. 7 .

Isotopic data for the 12 Silurian-Devonian waters reported here are shown in Fig. 8 relative to the meteoric water line (CRAIG, 1961) and standard mean ocean water (SMOW). A regression line has been drawn through 11 of the data points and present-day local meteoric water, excluding the sample from Wapella $\mathrm{E}$ field from consideration. The latter sample lies on the meteoric water line at a position consistent with precipitation under colder-than-present climatic conditions. This interpretation depends on an accurate evaluation of the isotopic composition of local meteoric water; a regression line can be drawn equally well through the 12 sample points alone (Fig. 7). The composition of lllinois meteoric water $\left(\delta \mathrm{D}=-40 \%, \delta^{18} \mathrm{O}=-6.3 \%\right)$ used by CLAYTON et al. (1966) agrees with analyses of precipitation collected over a oneyear period at Bondville in east-central Illinois (T. F. ANDERSON, pers. comm., 1989). CLAYTON et al. (1966) interpreted their $\delta \mathrm{D}-\delta^{18} \mathrm{O}$ trend in Illinois basin waters (Fig. 7) as the result of infiltration and subsequent isotopic alteration of meteoric water that originated as precipitation under climatic conditions not greatly different from those prevailing today. The regression lines in Fig. 7 suggest that the infiltrating meteoric water may have formed in part under somewhat colder-than-present climatic conditions.

In many sedimentary basins, chemical studies of brines have inferred the presence of remnant evaporated seawater; positive covariant $\delta \mathrm{D}-\delta^{18} \mathrm{O}$ relations in the same samples

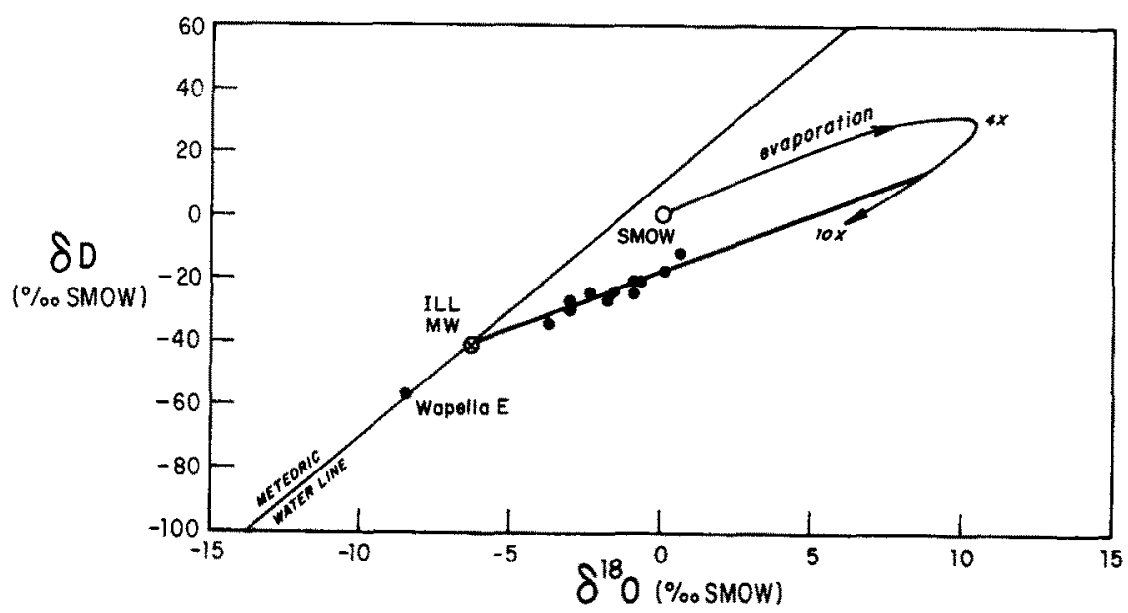

FIG. 8. Hydrogen-oxygen isotope compositions of 12 formation waters from Silurian and Devonian reservoirs in the Illinois basin, shown relative to the meteoric water line (CRAIG, 1961) and SMOW. ILL MW indicates the isotopic composition of present-day local meteoric water. A regression line, drawn through 11 of the data points and local meteoric water, has been extended to its intersection with the seawater evaporation trajectory of HOLSER (1979). 
could be interpreted as mixing trends between evaporated seawater and meteoric water. There has been a reluctance to accept such an interpretation, however, hecause the waters are commonly depleted in deuterium relative to SMOW, inconsistent with isotopic fractionation during seawater evaporation (LAND and PREZBINDOwSKI, 1981). During evaporation to the point of gypsum precipitation $(\sim 4 \times)$ residual seawater becomes enriched in the heavier isotopes (KNAUTH and BEEUNAS, 1986; following the work of GONFIANTINI, 1965; Holsfr, 1979; and PIERre et al., 1984), as shown in Fig. 8. However, with further evaporation toward halite saturation $(\sim 11 \times)$, residual liquid becomes progressively depleted in $\mathrm{D}$ and ${ }^{18} \mathrm{O}$, forming a curved or hooked trajectory. Therefore, evaporating seawater can yield a residual brine with a negative $\delta \mathrm{D}$ composition relative to SMOW.

Chloride-bromide relations (Fig. 3 b) indicate that original marine waters have not been completely expelled from $\mathrm{Si}$ lurian-Devonian strata. The $\delta \mathrm{D}-\delta^{18} \mathrm{O}$ trend in Fig. 8 is consistent with mixing of remnant brine with meteoric water, but the isotopic composition of the saline endmember is not well defined. The seawater evaporation trajectory in Fig. 8 was proposed by HOLSER (1979), but the shape and extent of the trajectory is variable and dependent on humidity and other local climatic conditions at the time of evaporation (SOFER and GAT, 1975; HOLSER, 1979; KNAUTH and BEEUNAS, 1986). Nevertheless, the $\delta \mathrm{D}-\delta^{18} \mathrm{O}$ trend line intersects the evaporation trajectory at a point beyond gypsum precipitation but prior to halite saturation, consistent with degree of seawater evaporation deduced from $\mathrm{Cl}-\mathrm{Br}$ relations. If the saline endmember was located on a seawater evaporation trajectory such as that shown in Fig. 8, these formation waters have been diluted by $50 \%$ or more with meteoric water.

According to the hypothesis of CLAYTON et al. (1966), the $\mathrm{O}$ isotope alteration of infiltrating metcoric water in the Illinois basin is due to isotope exchange between water and calcite, which results in a progressive enrichment of the water in ${ }^{18} \mathrm{O}$ with temperature and depth. The much smaller hydrogen isotope shift was not accounted for, due to lack of information on $\mathrm{H}$ isotope fractionation between water and hydrous minerals. It now seems unlikely that Illinois basin waters have been significantly affected by exchange of $\mathrm{H}$ isotopes with hydrous minerals in basin sediments. Although experimental data of O'NFII and KHARAKA (1976) and other workers strongly suggest $\mathrm{H}$ isotope exchange between clay minerals and water at temperatures below $100^{\circ} \mathrm{C}$, the integrated mineral/water ratio for hydrogen is generally very low in carbonate and coarse-grained clastic rocks so that little effect is actually observed (LONGSTAFFE, 1989). HITCHON and FRIEDMAN (1969) studied formation waters in the Alberta basin that revealed a $\delta \mathrm{D}-\delta^{18} \mathrm{O}$ trend similar to that abserved in Illinois basin waters. However, they attributed the trend to mixing of diagenetically altered remnant seawater with
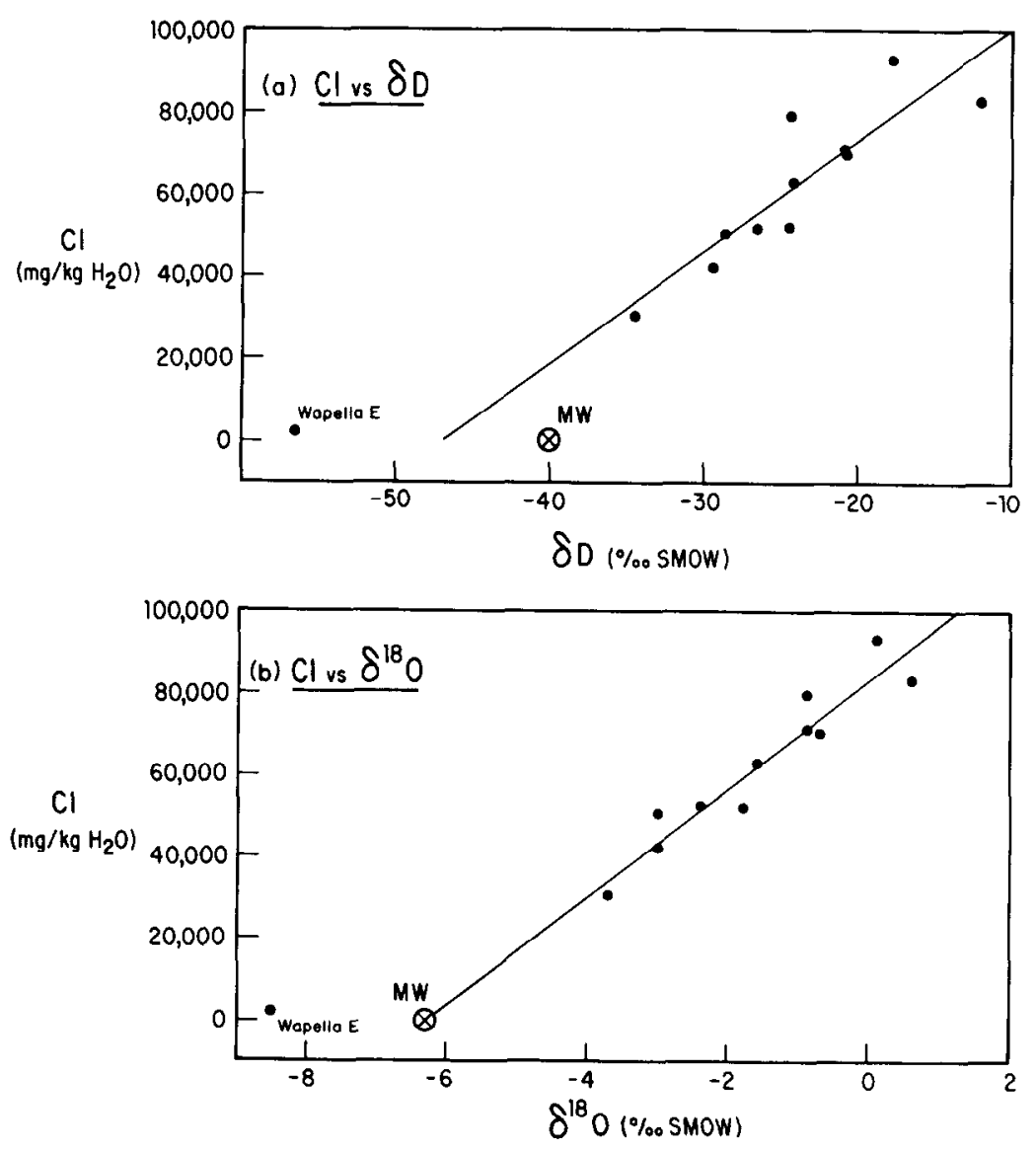

Fig. 9. Chloride concentrations in Silurian-Devonian waters as a function of hydrogen (a) and oxygen (b) isotope compositions. Chloride concentrations from Table 2 have been expressed in $\mathrm{mg} / \mathrm{kg} \mathrm{H}_{2} \mathrm{O}$. Regression lines have been drawn exclusive of Wapella $E$ sample and meteoric water (MW). 
infiltrating meteoric water. The remnant marine water was enriched in ${ }^{18} \mathrm{O}$ through extensive exchange of oxygen isotopes with the rock matrix, but variations in $\mathrm{H}$ isotopes were interpreted as reflecting the degree of mixing with meteoric water.

The relative importance of mixing versus diagenetic effects in determining the $\delta \mathrm{D}-\delta^{18} \mathrm{O}$ trend in Fig. 8 can be assessed through a comparison of the chemical and isotopic compositions of the formation waters. Whereas the mass of hydrogen in waters is large compared with that in hydrous minerals and other H-bearing compounds, exchangeable oxygen in minerals is large relative to oxygen in water. Thus, diagenetic effects on $\delta \mathrm{D}$ of formation waters may be negligible, especially at low temperatures, and covariant trends between $\delta \mathrm{D}$ and chemical constituents should reflect mixing of two dissimilar bodies of water. If a mixing event is thereby indicated, the relative contribution of diagenesis to $\delta^{18} \mathrm{O}$ variations can he evaluated from relations between $\delta^{18} \mathrm{O}$ and dissolved species.

The relation between $\delta \mathrm{D}$ and $\mathrm{Cl}$ concentration in SilurianDevonian formation waters is illustrated in Fig. 9a. Chloride (as well as other chemical species analyzed) shows a covariant relation with $\delta \mathrm{D}$; the regression line excludes the sample from Wapella $E$ field. Projection of the trend line to zero chemical concentration indicates an endmember $\delta \mathrm{D}$ composition approximately midway between present-day meteoric water and Wapella E formation water (Fig. 9a). This observation is consistent with the ambivalent relations between the $\delta \mathrm{D}-\delta^{18} \mathrm{O}$ regression lines in Fig. 7 and the isotopic composition of meteoric water. These formation-water samples probably contain a meteoric component that formed in part under colder-than-present climatic conditions. The Wapella E sample may represent water that is almost entirely of such an origin. CLAYTON et al. (1966) reported a number of samples that are isotopically lighter than present-day meteoric water (Fig. 7), similar in composition to the Wapella E water. SIEGEL and MANDLE (1984) concluded that recharge of Pleistocene glacial meltwater was responsible for isotopic compositions of waters from Cambrian-Ordovician strata in the north-central United States, including 12 samples from northern Illinois which showed $\delta \mathrm{D}$ and $\delta^{18} \mathrm{O}$ values virtually identical to those of Wapella $E$ water. Covariant chemical $-\delta D$ relations such as that in Fig. 9a support our interpretation that the $\delta \mathrm{D}-\delta^{18} \mathrm{O}$ trend in Fig. 8 represents a mixing event between remnant marine water and meteoric water.

When $\mathrm{Cl}$ concentration is plotted as a function of $\delta^{18} \mathrm{O}$ (Fig. 9b), a covariant relation almost identical to that in Fig. $9 \mathrm{a}$ is obtained. In this case, however, projection of the trend to zero concentration coincides with the $\delta^{18} \mathrm{O}$ composition of present-day meteoric water. Covariant chemical $-\delta^{18} \mathrm{O}$ trends such as that in Fig. 9b indicate that $\delta^{18} \mathrm{O}$ variations have been produced primarily by a mixing event between a remnant marine water and meteoric water. KNAUTH and BEEUNAS (1986) pointed out that $\delta \mathrm{D}$ covariance with $\delta^{18} \mathrm{O}$ in formation waters suggests that whatever is causing the $\delta \mathrm{D}$ variations may also be affecting the ${ }^{18} \mathrm{O} /{ }^{16} \mathrm{O}$ ratios. If the meteoric water component had an isotopic composition as indicated by the $\delta \mathrm{D}$ trend in Fig. $9 \mathrm{a}(\delta \mathrm{D} \sim-48 \%)$, then the trend in Fig. $9 \mathrm{~b}$ suggests a small oxygen isotope enrichment $(\sim+0.9 \%)$ due to exchange between waters and carbonates.

The precise isotopic composition of meteoric waters that have infiltrated the Illinois basin can only be resolved by a more thorough isotopic study using current analytical methods, but our limited data infer that oxygen isotope exchange with calcite could have played only a very small role in establishing the $\delta \mathrm{D}$ and $\delta^{18} \mathrm{O}$ trends in basin waters. We conclude that covariance of $\delta \mathrm{D}$ and $\delta^{18} \mathrm{O}$ in Illinois basin waters is due to infiltration of meteoric waters which have mixed with remnant cvaporated seawater, and that the increases in $\delta \mathrm{D}$ and $\delta^{18} \mathrm{O}$ with water salinity observed by CLAYTON et al. (1966) are a manifestation of this mixing process. Our observations in the Illinois basin are in accord with the suggestion of KNAUTH and BEEUNAS (1986) that remnant evaporite brines may be more commonly preserved in sedimentary basins than isotopic arguments have previously indicated.

The age of the meteoric water component in the SilurianDevonian formation waters is difficult to evaluate. Our isotopic data and that of CI AYTON et al. (1966) suggest that the water entered the subsurface when the climate was not greatly different from that of the present. However, samples from shallow wells near recharge areas have isotopic compositions which infer that the meteoric component formed under colder-than-present conditions, probably during the Pleistocene epoch. Therefore, the meteoric water in the deeper brines must be pre-Pleistocene in age (CLAYTON et al., 1966). Changes in local climatic conditions before the Pleistocene cannot be assessed adequately. The isotopic composition of seawater and the position of the meteoric water line have remained essentially constant for at least the last $150 \mathrm{Ma}$ (IAYLOR, 1979) and probably since at least Permian time (KNAUTH and BEEUNAS, 1986).

\section{STRONTIUM ISOTOPE RELATIONS: MIXING WITH A RADIOGENIC FLUID}

Most samples reported here had been analyzed for $\mathrm{Sr}$ isotope ratios (STUEBER et al., 1987). The range of ${ }^{87} \mathrm{Sr} /{ }^{86} \mathrm{Sr}$ ratios in Silurian-Devonian waters $(0.7092-0.7108)$ is variably more radiogenic than the range of scawater values for this interval of geologic time (BURKE et al., 1982), indicating that a portion of the dissolved $\mathrm{Sr}$ had been acquired from a detrital source material. When the sample data were plotted within coordinates of ${ }^{87} \mathrm{Sr} /{ }^{86} \mathrm{Sr}$ and $1 / \mathrm{Sr}$, a linear pattern with a positive slope was revealed. It was proposed that the SilurianDevonian waters show a two-component mixing relation, suggesting that they comprise a single hydrogeological system that evolved when ${ }^{87} \mathrm{Sr}$-enriched water and petroleum from New Albany shales entered Silurian-Devonian carbonate rocks and mixed with marine interstitial water.

When ${ }^{87} \mathrm{Sr} /{ }^{86} \mathrm{Sr}$ ratios are plotted versus concentrations of major and minor elements (Table 2) other than $\mathrm{Sr}$, no evidence for a mixing trend is found in any case. The relation between ${ }^{87} \mathrm{Sr} /{ }^{86} \mathrm{Sr}$ and $\mathrm{Sr}$ suggests a hyperbolic mixing trend, but one with considerable internal scatter. Normalization of elements to Cl concentrations to compensate for meteoric water dilution does not improve the relations among elemental data and $\mathrm{Sr}$ isotopic composition. If the two-component mixing event suggested by the $\mathrm{Sr}$ isotope data involved formation waters of significantly different chemical compositions, subsequent chemical modifications due to water-rock interactions have masked mixing trends between ${ }^{87} \mathrm{Sr} /{ }^{86} \mathrm{Sr}$ 
and major and minor elements other than Sr. Even Sr concentrations seem to have been diagenetically modified to a significant extent.

Mixing relations among formation waters can also be investigated through element versus element plots. If linear concentration scales are used, conservative mixing trends will be represented by straight lines (HANOR, 1987). When the concentrations of any pair of the elements $\mathrm{Na}, \mathrm{Ca}, \mathrm{Mg}, \mathrm{K}$, $\mathrm{Sr}, \mathrm{Cl}$, and $\mathrm{Br}$ in the Silurian-Devonian waters are plotted within such coordinates, sub-linear trends directed toward the origin are obtained, as illustrated by $\mathrm{Ca}$ versus $\mathrm{Na}$ in Fig. 10. The general trend of the data points reflects the dominant mixing event between remnant evaporated seawater and meteoric water, whereas the scatter of points about the trend has apparently been produced by chemical modifications through water-rock interactions.

Water samples that represent mixtures of two components in different proportions will form a straight-line relation in the coordinates ${ }^{87} \mathrm{Sr} /{ }^{86} \mathrm{Sr}$ versus $1 / \mathrm{Sr}$ (FAURE, 1986). Data for 46 Silurian-Devonian water samples are shown within these coordinates in Fig. 11a. The scatter within the general trend of data points could be caused by dilution and precipitation effects on $\mathrm{Sr}$ concentrations, which would displace points parallel to the abscissa. Normalization of $\mathrm{Sr}$ to $\mathrm{Cl}$, to compensate for dilution, does not appreciably diminish the scatter of points. Scatter of data points in Fig. 1 la may also be due to modification of ${ }^{87} \mathrm{Sr} /{ }^{86} \mathrm{Sr}$ ratios by local water-rock interactions.

We have examined intra-field variability in elemental and Sr isotopic composition by analyzing six samples from closely spaced wells in Bartelso E field, producing from a Silurian reef. The results (Table 2; samples 256-262) show a high degree of chemical uniformity for major and minor elements with the exception of $\mathrm{Ca}, \mathrm{Sr}$, and $\mathrm{SO}_{4}$. Strontium concentrations range from 204 to $345 \mathrm{mg} / \mathrm{L}$ in the six samples, but ${ }^{87} \mathrm{Sr} /{ }^{86} \mathrm{Sr}$ ratios are essentially constant. Locations of data points for these samples are indicated in Fig. $11 \mathrm{a}$; their significant lateral separation must be due to a process other than metcoric watcr dilution bccause the samples have essentially uniform concentrations of conservative elements such as $\mathrm{Cl}$. Precipitation of solids that incorporate $\mathrm{Sr}$ also could displace data parallel to the abscissa because $\mathrm{Sr}$ isotopic fractionation would not have taken place during the process. Strontium is incorporated as a minor constituent in gypsum, anhydrite, and calcite. Calcium concentrations in the six samples are quite variable, ranging from 6380 to $9090 \mathrm{mg}$ / $\mathrm{L}$, and $\mathrm{SO}_{4}$ concentrations range from 93 to $1367 \mathrm{mg} / \mathrm{L}$ (Table 2). It seems quite possible that precipitation of gypsum or anhydrite in the reservoir rock is causing the intra-field variability of $\mathrm{Ca}$ and $\mathrm{Sr}$.

Because sulfate concentrations in Silurian-Devonian formation waters are highly variable (Table 2 ) and because this variability is not related to meteoric water dilution, local precipitation of gypsum, anhydrite, or calcite in the carbonate reservoir rocks may have had a significant effect on the $\mathrm{Sr}$ contents of many of the samples. Multiple water samples from each of nine individual oil fields show that intra-field Sr variability is common, whereas ${ }^{87} \mathrm{Sr} /{ }^{86} \mathrm{Sr}$ ratios are internally quite consistent (Table 2). In examining the data for a two-component mixing relationship it therefore seems appropriate to use only the sample with maximum $\mathrm{Sr}$ concentration from each field to minimize possible effects of postmixing precipitation. These data have been plotted in Fig. $11 \mathrm{~b}$ along with the data for each of 18 fields represented by a single water sample. The scatter of data points is reduced relative to that in Fig. $11 \mathrm{a}$, as indicated by a correlation coefficient of 0.74 compared with a value of 0.62 when all samples are considered. It seems likely that further improvement in definition of a trend line would have been obtained if this approach had been applied to the 18 fields represented by only one sample. Clearly, in future work of this nature, multiple samples should be analyzed from each oil field in order to evaluate the effects of local diagenetic processes on Sr concentrations in formation waters.

Although $\mathrm{Sr}$ concentrations of Silurian-Devonian waters have been diagenetically modified to some extent, there is evidence of a positive correlation between ${ }^{87} \mathrm{Sr} /{ }^{86} \mathrm{Sr}$ and $1 / \mathrm{Sr}$ (Fig. $11 \mathrm{~b}$ ), which suggests that a two-component mixing event may have taken place. A mixing line has been drawn through the points representing waters which apparently experienced minimal diagenetic modification (i.e., highest $\mathrm{Sr}$ contents). The positive slope of the line indicates that the proposed

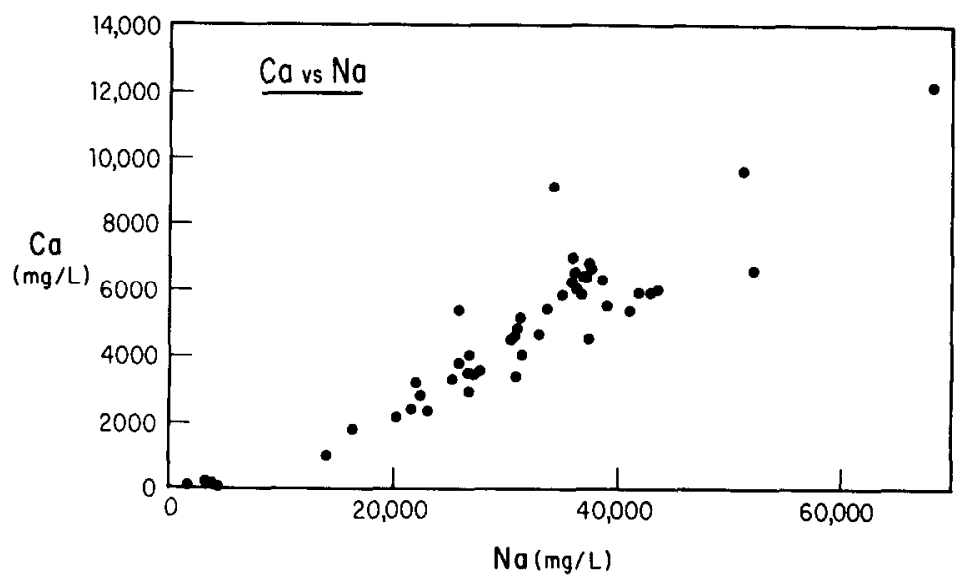

FIG. 10. Calcium vs. sodium relations in formation-water samples from Silurian and Devonian reservoirs in the Illinois basin including five dilute samples from the northern perimeter of the basin. 

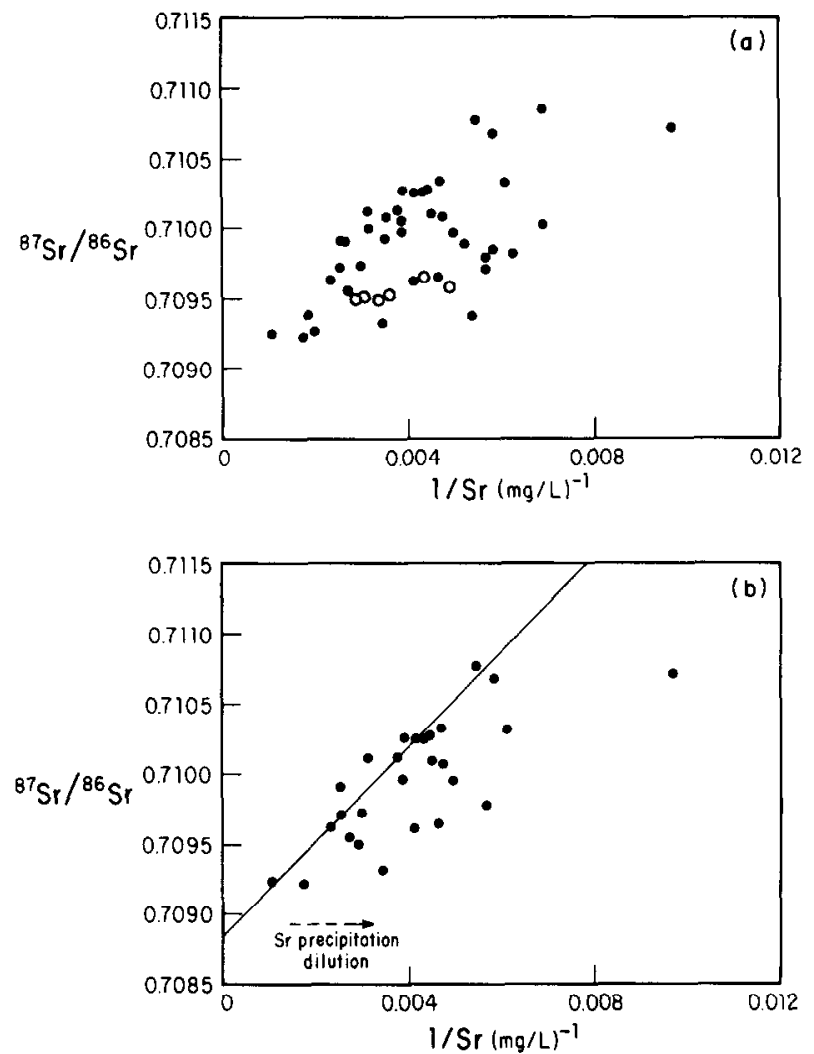

FIG. 11. (a) ${ }^{87} \mathrm{Sr} /{ }^{86} \mathrm{Sr}$ vs. $1 / \mathrm{Sr}$ relations in 46 formation-water samples from Silurian and Devonian reservoirs in the Illinois basin. Open circles represent samples from Bartelso E Field. (b) ${ }^{87} \mathrm{Sr} /{ }^{86} \mathrm{Sr}$ vs. $1 / \mathrm{Sr}$ relations for 27 oil fields producing from Silurian and Devonian reservoirs, using only the sample with maximum $\mathrm{Sr}$ concentration from each field. A mixing line has been drawn through data points that represent waters which apparently experienced minimal diagenetic modification.

mixing involved a formation water with a relatively high ${ }^{87} \mathrm{Sr} /$ ${ }^{86} \mathrm{Sr}$ ratio and low $\mathrm{Sr}$ concentration, and another formation water characterized by a relatively low ${ }^{87} \mathrm{Sr} /{ }^{86} \mathrm{Sr}$ ratio and high $\mathrm{Sr}$ concentration. The ${ }^{87} \mathrm{Sr} /{ }^{86} \mathrm{Sr}$ intercept of the mixing line at 0.7088 is compatible with Silurian seawater values (BURKE et al., 1982), suggesting that one of the components was remnant evaporated seawater in the carbonate strata.

Association of the present formation waters with petroleum accumulations undoubtedly derived from stratigraphically adjacent New Albany shales (BARRows and CLUFF, 1984) suggests that the ${ }^{87} \mathrm{Sr}$-cnriched component water acquired radiogenic $\mathrm{Sr}$ from the petroleum source rock. Because $\mathrm{Si}$ lurian and Devonian oil production occurs mostly toward the margins of the basin (Fig. 1), well away from the area of probable oil generation in southeastern Illinois (BARROws and CLuFF, 1984), the ${ }^{87}$ Sr-enriched fluid and petroleum must have migrated relatively great distances through the carbonate strata while mixing with marine interstitial water in different proportions. Such long-range migration of New Albany fluids is consistent with the organic geochemical studies of BETHKE et al. (1991) which correlated thermally mature New Albany shale in southeastern Illinois with petroleum from Silurian reservoirs in central Illinois. Notably, because ${ }^{87} \mathrm{Sr} /{ }^{86} \mathrm{Sr}$ ratios of Silurian-Devonian formation waters are not correlated with $\delta \mathrm{D}$ or $\delta^{18} \mathrm{O}$ values, mixing between remnant evaporated seawater and a ${ }^{87} \mathrm{Sr}$-enriched fluid and dilution with meteoric water cannot represent a single mixing event.

The positive correlation between ${ }^{87} \mathrm{Sr} /{ }^{86} \mathrm{Sr}$ and $1 / \mathrm{Sr}$ in Fig. 11 must have significance in terms of the evolutionary history of Silurian-Devonian formation waters despite scatter of data points within the general trend. Water samples from Mississippian and Pennsylvanian sandstone reservoirs in the Illinois basin show no correlation between these parameters, apparently because extensive cross-formational migration of New Albany fluids resulted in major diagenetic modification of the Sr isotope system (STUEBER et al., 1987). We have analyzed 27 formation-water samples from another important carbonate reservoir, the Mississippian Ste. Genevieve Limestone (unpubl. data), which also reveal completely unsystematic relations between ${ }^{87} \mathrm{Sr} /{ }^{86} \mathrm{Sr}$ and $1 / \mathrm{Sr}$. It is clear that waterrock interactions have affected concentrations of all the major and minor cations in the Silurian-Devonian formation waters, but the effects on Sr were sufficiently small to preserve evidence of a mixing relation. Although most of the scatter of data in Fig. 11 is probably due to local diagenetic modification in $\mathrm{Sr}$ concentrations, it is also likely that ${ }^{87} \mathrm{Sr}$-enriched water from New Albany shales was not entirely homogeneous in its ${ }^{87} \mathrm{Sr} /{ }^{86} \mathrm{Sr}$ and $\mathrm{Sr}$ content prior to mixing. The $\mathrm{Sr}$ isotope data, in conjunction with $\mathrm{Cl}-\mathrm{Br}$ and $\delta \mathrm{D}-\delta^{18} \mathrm{O}$ relations, indicate that Silurian-Devonian formation waters represent three-component mixtures involving remnant evaporated Silurian-Devonian seawater, a ${ }^{87} \mathrm{Sr}$-enriched fluid that probably migrated from New Albany shales, and a major component of meteoric water. Mixing between remnant evaporated seawater and the ${ }^{87} \mathrm{Sr}$-enriched fluid probably preceded dilution with meteoric water.

\section{SUMMARY}

Chemical and isotopic analyses of formation waters from Silurian-Devonian strata in the Illinois basin provide evidence
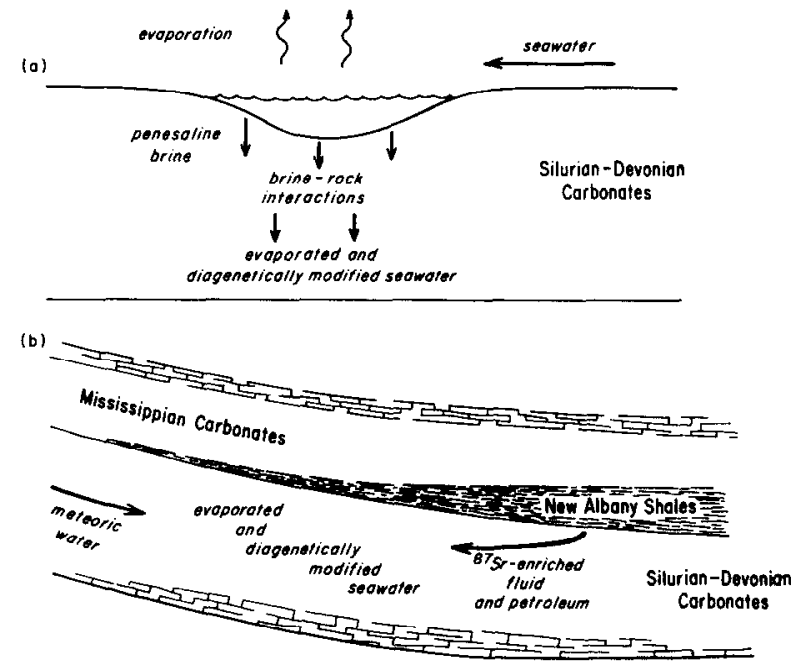

FIG. 12. (a) Schematic diagram showing subaerial evaporation of Silurian-Devonian seawater in the Illinois basin, followed by chemical modification of the penesaline brine in the subsurface. (b) Schematic diagram showing subsequent mixing of the remnant brine with a ${ }^{87} \mathrm{Sr}$-enriched fluid from New Albany shales and with meteoric water from recharge areas. 
of the geologic processes and events responsible for present brine compositions (Fig. 12). Chloride-bromide relations indicate that Silurian-Devonian seawater evaporated to a point short of halite saturation in a subtropical, restricted shallowmarine environment. After this penesaline water entered the subsurface, diagenetic processcs transformed the $\mathrm{K}, \mathrm{Mg}$-rich brine into a $\mathrm{Na}-\mathrm{Ca}-\mathrm{Cl}$ formation water. Comparisons of cation/Br ratios with corresponding ratios in evaporating seawater provide quantitative evaluation of $\mathrm{Na}$ and $\mathrm{K}$ depletion through interaction with clay minerals, $\mathrm{Ca}$ enrichment and $\mathrm{Mg}$ depletion by dolomitization of carbonates, and $\mathrm{Sr}$ enrichment as a result of $\mathrm{CaCO}_{3}$ recrystallization and dolomitization. Strontium isotope analyses of the formation waters suggest mixing between diagenetically modified brine and a ${ }^{87} \mathrm{Sr}$-enriched fluid that probably migrated, along with petroleum, into Silurian-Devonian carbonates from stratigraphically adjacent New Albany shales. Covariance of $\delta \mathrm{D}$ and $\delta^{18} \mathrm{O}$ in the formation waters reveals mixing with a significant component of meteoric water that diluted the remnant evaporated seawater by as much as $50 \%$ or more. Thus, present Silurian-Devonian formation waters are interpreted as mixtures of fluids from three different sources.

These results suggest that high salinities in Illinois basin waters from Silurian-Devonian strata have not been produced by halite dissolution or by shale-membrane filtration of marine pore fluids and/or meteoric water. Furthermore, the presence of remnant evaporated seawater indicates that the original marine waters have not been completely expelled and replaced by meteoric water. Thus, if gravity-driven recharge has occurred in these reservoirs, it was insufficient to displace completely the dense brines. The $\delta \mathrm{D}-\delta^{18} \mathrm{O}$ trend in Silurian-Devonian waters is the result of mixing between brines and meteoric water. Isotope exchange with minerals apparently played a very limited role in establishing the $\delta \mathrm{D}$ $-\delta^{18} \mathrm{O}$ relations.

Acknowledgments-Acknowledgment is made to the donors of The Petroleum Research Fund, administered by the American Chemical Society, for partial support of this research under Grants PRF-18640AC2 (LMW) and PRF-20576-B2 (AMS). Additional support was provided by NSF Grant EAR-8657180 (LMW) and by Chevron Oil Field Research Company. We appreciate the invaluable technical assistance of $T$. J. Huston during the course of the analytical work. L. P. Knauth is thanked for providing both stable isotope analyses and critical comments and discussions on isotope systematics in brines. T.F. Anderson kindly provided oxygen isotope data for precipitation at Bondville, IL. Discussions with A. B. Carpenter and C. A. Connolly were extremely beneficial. B. H. Wilkinson and R. K. Given provided valuable criticism of an early draft of the manuscript. We appreciate the very helpful comments of journal reviewers I. E. Hutcheon, F. J. Longstaffe, and R. H. McNutt, as well as those of associate editor H. P. Schwarcz. Paula Kunde is thanked for typing the manuscript.

\section{Editorial handling: H. P. Schwarcz}

\section{REFERENCES}

BarRows M. II. and ClufF R. M. (1984) New Albany Shale Group (Devonian-Mississippian) source rocks and hydrocarbon generation in the Illinois basin. In Petroleum Geochemistry and Basin Evaluation (eds. G. Demaison and R. J. Murris); Amer. Assoc. Petrol. Geol. Mem. 35, pp. 111-138.
BETHKE C. M. (1986) Hydrologic constraints on the genesis of the Upper Mississippi Valley mineral district from Illinois basin brines. Econ. Geol. 81, 233-249.

BethKe C. M., ReEd J. D., Barrows M. H., and Oltz D. F. (1991) Long-range petroleum migration in the Illinois Basin. In Interior Cratonic Sag Basins, Petroleum Basins Series (ed. M. W. LEIGHToN). Amer. Assoc. Petrol. Geol. (in press).

BOND D. C. (1972) Hydrodynamics in deep aquifers of the Illinois basin. Illinois State Geol. Survey Circ. 470

Burke W. H., Denison R. E., Hetherington E. A., Koepnick R. B., NELSON H. F., and OTTO J. B. (1982) Variation of seawater ${ }^{87} \mathrm{Sr} /{ }^{86} \mathrm{Sr}$ throughout Phanerozoic time. Geology 10, 516-519.

BUSCHBACH T. C. and ATHERTON E. (1979) History of the structural uplift of the southern margin of the Illinois basin. In Deposition and Structural History of the Pennsylvanian System of the Illinois Basin (eds. J. E. PALMER and R. R. DUtCHER), Illinois Siate Geol. Surv. Guidebook $15 a$, pp. 112-115.

CARPENTER A. B. (1978) Origin and chemical evolution of brines in sedimentary basins. Oklahoma Geol. Survey Circ. 79, 60-77.

CASAS E. and LOWENSTEIN T. K. (1989) Diagenesis of saline pan halite: Comparison of petrographic features of Modern, Quaternary and Permian halites. J. Sediment. Petrol. 59, 724-739.

Clayton R. N., Friedman I., Graf D. L., Mayeda T. K., Meents W. F., and SHIMP N. F. (1966) The origin of saline formation waters: I. Isotopic composition. J. Geophys. Res. 71, 3869-3882.

Coburn G. W. (1986) Silurian of the Illinois basin: A carbonate ramp. Oil Gas J. 84, 96-100.

CRAIG H. (1961) Isotopic variations in meteoric waters. Science 133, $1702-1703$.

Das N., HoRita J., and Holland H. D. (1990) Chemistry of fluid inclusions in halite from the Salina Group of the Michigan Basin: Implications for Late Silurian seawater and the origin of sedimentary brines. Geochim. Cosmochim. Acta 54, 319-327.

EGEBERG P. K. and AAGAARD P. (1989) Origin and evolution of formation waters from oil fields on the Norwegian shelf. Appl. Geochem. 4, 131-142

EPSTEIN S. and MAYEDA T. (1953) The variation in ${ }^{18} \mathrm{O}$ content of water from natural sources. Geochim. Cosmochim. Acta 4, 213224.

FAURE G. (1986) Principles of Isotope Geology, 2nd edn. J. Wiley \& Sons.

GONFIANTINI R. (1965) Effetti isotopici nell'evaporazione di acque salate. Alti. Soc. Tosc. Sci. Nat., Ser. A, 72

GRAF D. L. (1982) Chemical osmosis, reverse chemical osmosis, and the origin of subsurface brines. Geochim. Cosmochim. Acta 46, $1431-1448$.

GraF D. L., Friedman 1., and MeEnts W. F. (1965) The origin of saline formation waters: II. Isotopic fractionation by shale micropore systems. Illinois State Geol. Surv. Circ. 393.

Graf D. L., Meents W. F., Friedman I., and Shimp N. F. (1966) The origin of saline formation waters: III. Calcium chloride waters. Illinois State Geol. Surv. Circ. 397

HANOR J. S. (1979) The sedimentary genesis of hydrothermal fluids. In Geochemistry of Hydrothermal Ore Deposits (ed. H. L. BARNES), pp. 137-168. J. Wiley \& Sons.

HANOR J. S. (1983) Fifty years of development of thought on the origin and evolution of subsurface sedimentary brines. In Revolution in the Earth Sciences (ed. S. J. BOARDMAN), pp. 99-111. Kendall-Hunt.

HANOR J. S. (1987) Origin and Migration of Subsurface Sedimentary Brines; Soc. Econ. Paleon. Mineral. Short Course 21.

Heidlaur D. T., Hsui A., and KLEIN G. DEV. (1986) Tectonic subsidence analysis of the Illinois basin. J. Geol. 94, 779-794.

HITCHON B. and FRIEDMAN I. (1969) Geochemistry and origin of formation waters in the western Canada sedimentary basin: I. Stable isotopes of hydrogen and oxygen. Geochim. Cosmochim. Acta 33 $1321-1349$

HOLLAND H. D. (1978) The Chemistry of the Atmosphere and Oceans J. Wiley \& Sons.

HOLSER W. (1979) Trace elements and isotopes in evaporites. In Marine Minerals (ed. R. G. BURNS); Reviews in Mineralogy 6, pp. 295-346. 
KeLLER S. J. (1983) Analyses of subsurface brines of Indiana. Dept. Natural Res. Geol. Surv. Occ. Pap. 41.

Kharaka Y. K., Maest A. S., Carothers W. W., LaW L. M., LAMOTHE P. J., and FRIES T. L. (1987) Geochemistry of metalrich brines from central Mississippi Salt Dome basin, U.S.A. Appl. Geochem. 2, 543-561.

KNAUTh L. P. (1988) Origin and mixing history of brines, Palo Duro Basin, Texas, U.S.A. Appl. Geochem. 3, 455-474.

KNAUTH L. P. and BeEUNAS M. A. (1986) Isotope geochemistry of fluid inclusions in Permian halite with implications for the isotopic history of ocean water and the origin of saline formation waters. Geochim Cosmochim. Acta 50, 419-433.

LAND L. S. (1987) The major ion chemistry of saline brines in sedimentary basins. In Physics and Chemistry of Porous Media II (eds. J. R. Banavar et al.); Amer. Inst. Phys. Conf. Proc. 154, pp. 160-179.

Land L. S. and Prezbindowski D. R. (1981) The origin and evolution of saline formation water, Lower Cretaceous carbonates, south-central Texas, U.S.A. J. Hydrol. 54, 51-74.

LAND L. S. and PrezbinDowsKI D. R. (1985) Chemical constraints and origins of four groups of Gulf Coast reservoir fluids: Discussion. Bull. Amer. Assoc. Petrol. Geol. 69, 119-121.

LAND L. S., KuPECZ J. A., and MACK L. E. (1988) Louann Salt geochemistry (Gulf of Mexico Sedimentary Basin, U.S.A.): A preliminary synthesis. Chem. Geol. 74, 25-35.

LONGSTAFFE F. J. (1989) Stable isotopes as tracers in clastic diagenesis. In Short Course in Burial Diagenesis (ed. I. E. HuTCHEON); Mineral. Assoc. Canada Short Course Ser. 15, pp. 201-277.

MrCaffrfy M. A., I azar B., and Holland H. D. (1987) The evaporation path of seawater and the coprecipitation of $\mathrm{Br}^{-}$and $\mathrm{K}^{+}$with halite. J. Sediment. Petrol. 57, 928-937.

MCGRAIN P. and HELTON W. L. (1964) Gypsum and anhydrite in the St. Louis Limestone in northwestern Kentucky. Kentucky Geol. Surv. Inf. Circ. 13.

MCGREGOR D. J. (1954) Gypsum and anhydrite deposits in southwestern Indiana. Indiana Geol. Survey Prog. Rept. No. 8.

MEenTS W. F., Bell A. H., Rees O. W., and TilbuRY W. G. (1952) Illinois oil-field brines, their geological occurrence and chemical composition. Illinois State Geol. Surv., Illinois Petrol. 66.

NesbitT H. W. (1980) Characterization of mineral-solution interactions in Carboniferous sandstones and shales of the Illinois sedimentary basin. Amer. J. Sci. 280, 607-630.

NesBirt H. W. (1985) A chemical equilibrium model for the Illinois basin formation waters. Amer. J. Sci. 285, 436-458.

O'NEIL J. R. and KHARAKA Y. K. (1976) Hydrogen and oxygen isotope exchange reactions between clay minerals and water. Geochim. Cosmochim. Acta 40, 241-246.

Pierre C., Ortlieb L., and Person A. (1984) Supratidal evaporitic dolomite at Ojo de Liebre lagoon: Mineralogical and isotopic arguments for primary crystallization. J. Sediment. Petrol. 54, 10491061.

Popp B. N., Podosek F. A., Brannon J. C., ANDERson T. F., and PIER J. (1986) ${ }^{87} \mathrm{Sr} /{ }^{86} \mathrm{Sr}$ ratios in Permo-Carboniferous sea water from the analyses of well-preserved brachiopod shells. Geochim. Cosmochim. Acta 50, 1321-1328.

POTTER P. E. (1962) Late Mississippian sandstones of Illinois. Illinois State Geol. Surv. Circ. 340.

PotTer P. E. and Glass H. D. (1958) Petrology and sedimentation of the Pennsylvanian sediments in southern Illinois: A vertical profile. Illinois State Geol. Surv. Rept. Inv. 204.

RILEY J. P. and CHESTER R. (1971) Iniroduction to Marine Chemistry: Academic Press.
RITteniouse G. (1967) Bromine in oil-field waters and its use in determining possibilities of origin of these waters. Bull. Amer. Assoc. Petrol. Geol. 51, 2430-2440.

SAXBY D. E. and LAMAR J. E. (1957) Gypsum and anhydrite in Illinois. Illinois State Geol. Surv. Circ. 226.

SIEGEL D. I. and MANDLE R. J. (1984) Isotopic evidence for glacial meltwater recharge to the Cambrian-Ordovician aquifer, northcentral United States. Quat. Res. 22, 328-335.

SOFER Z. and GAT J. R. (1972) Activities and concentrations of oxygen-18 in concentrated aqueous salt solutions: Analytical and geophysical implications. Earth Planet. Sci. Lett. 15, 232-238.

SOFER Z. and GAT J. R. (1975) The isotope composition of evaporating brines: Effect of the isotopic activity ratio in saline solutions. Earth Planet. Sci. Lett. 26, 179-186.

SPENCER R. J. (1987) Origin of Ca-Cl brines in Devonian formations, western Canada sedimentary basin. Appl. Geochem. 2, 373-384.

Stevenson D. L., Chamberlin T. L., and Buschbach T. C. (1975) Insoluble residues of the Sauk Sequence (Cambrian and Lower Ordovician) rocks of the Fairfield basin, Illinois: An aid in correlation and in petroleum exploration. Illinois State Geol. Surv., Illinois Petrol. 106.

Stoessell R. K. and CARPenter A. B. (1986) Stoichiometric saturation tests of $\mathrm{NaCl}_{1-\mathrm{x}} \mathrm{Br}_{\mathrm{x}}$ and $\mathrm{KCL}_{1-\mathrm{x}} \mathrm{Br}_{\mathrm{x}}$. Geochim. Cosmochim. Acta 50, 1465-1474.

Stoessell R. K. and Moore C. H. (1983) Chemical constraints and origins of four groups of Gulf Coast reservoir fluids. Bull. Amer. Assoc. Petrol. Geol. 67, 896-906.

Stoessell R. K. and MoOre C. H. (1985) Chemical constraints and origins of four groups of Gulf Coast reservoir fluids: Reply Bull. Amer. Assoc. Petrol. Geol. 69, 122-126.

Stueber A. M., Pushkar P., and Hetherington E. A. (1987) A strontium isotopic study of formation waters from the Illinois basin, U.S.A. Appl. Geochem. 2, 477-494.

SWANN D. H. (1967) A summary geological history of the Illinois basin. In Geology and Petroleum Production of the Illinois Basin, pp. 3-21. Illinois Geol. Soc.

Swann D. H. and Willman H. B. (1961) Megagroups in Illinois. Bull. Amer. Assoc. Petrol. Geol. 45, 471-483.

TAYLOR H. P., JR. (1979) Oxygen and hydrogen isotope relationships in hydrothermal mineral deposits. In Geochemistry of Hydrothermal Ore Deposits (ed. H. L. BARNES), pp. 236-277. J. Wiley \& Sons.

VAN DER VOO R. (1988) Paleozoic paleogeography of North America, Gondwana, and intervening displaced terranes: Comparisons of paleomagnetism with paleoclimatology and biogeographical patterns. Bull. Geol. Soc. Amer. 100, 311-324.

WAlter L. M., Stueber A. M., and Huston T. J. (1990) Br-Cl$\mathrm{Na}$ systematics in Illinois Basin fluids: Constraints on fluid origin and evolution. Geology 18, 315-318.

WHITAKER S. T. (1988) Silurian pinnacle reef distribution in Illinois: Model for hydrocarbon exploration. Illinois State Geol. Surv., Illinois Petrol. 130.

Willman H. B., Atherton E., Buschbach T. C., Collinson C., Frye J. C., Hopkins M. E., Lineback J. A., and Simon J. A. (1975) Handbook of Illinois stratigraphy. Illinois State Geol. Surv. Bull. 95.

WILSON T. P. and LONG D. T. (1984) The behavior of bromide during the dissolution of halite at $25^{\circ} \mathrm{C}$ and 1 atm (abstr.). Geol. Soc. Amer., Abstr. Prog. 16, 697.

ZherebTSOVA I. K. and VOLKOVA N. N. (1966) Experimental study of behavior of trace elements in the process of natural solar evaporation of Black Sea water and Sasyk-Sivash brine. Geochem. Int. $3,656-670$ 